\title{
Specific and general stress proteins in Bacillus subtilis - a two-dimensional protein electrophoresis study
}

\author{
Jörg Bernhardt, ${ }^{1}$ Uwe Völker, ${ }^{1}$ Andrea Völker, ${ }^{1}$ Haike Antelmann, ${ }^{1}$ \\ Roland Schmid, ${ }^{2}$ Hiltraut Mach ${ }^{1}$ and Michael Hecker ${ }^{1}$
}

Author for correspondence: Michael Hecker. Tel: +493834 864201. Fax: +493834864202.

e-mail: hecker@microbio7.biologie.uni-greifswald.de

1 Institut für Mikrobiologie und Molekularbiologie, Ernst-Moritz-ArndtUniversităt Greifswald, 17487 Greifswald, Friedrich-Ludwig-JahnStraße 15, Germany

2 Universität Osnabrück, Abteilung für Mikrobiologie, 49076 Osnabrück, Germany

\begin{abstract}
A computer-aided analysis of high resolution two-dimensional polyacrylamide gels was used to investigate the changes in the protein synthesis profile in $B$. subtilis wild-type strains and sigB mutants in response to heat shock, salt and ethanol stress, and glucose or phosphate starvation. The data provided evidence that the induction of at least $\mathbf{4 2}$ general stress proteins absolutely required the alternative sigma factor $\sigma^{8}$. However, at least seven stress proteins, among them ClpC, ClpP, Sod, AhpC and AhpF, remained stressinducible in a sigB mutant. Such a detailed analysis also permitted the description of subgroups of general stress proteins which are subject to additional regulatory circuits, indicating a very thorough fine-tuning of this complex response. The relative synthesis rate of the general stress proteins constituted up to $40 \%$ of the total protein synthesis of stressed cells and thereby emphasizes the importance of the stress regulon. Besides the induction of these general or rather unspecific stress proteins, the induction of stress-specific proteins is shown and discussed.
\end{abstract}

Keywords: Bacillus subtilis, sigB, stress response, two-dimensional electrophoresis, protein index

\section{INTRODUCTION}

In contrast to the optimal growth conditions in the laboratory, $B$. subtilis cells spend most of their life time in a starving or non-growing state because of the many stressful environmental conditions in their natural ecosystem, the soil. To face stress and starvation, $B$. subtilis cells have developed a very complex adaptational network, inside of which the induction of general or unspecific stress proteins seems to be a very important component (for a review, see Hecker et al., 1996). The decrease in the synthesis of house-keeping proteins accompanied by the most prominent induction of a set of about 50 proteins, which are induced by many different environmental stimuli, is one of the earliest and most dramatic responses of the $B$. subtilis cell to the transition from a growing to a non-growing state.

This general stress response may provide a rather unspecific protective function in the non-growing cell, regardless of the specific stimulus, like the $\sigma^{\mathrm{s}}$-dependent

Abbreviation: 2-D, two-dimensional. general stress and starvation response of Escherichia coli (Loewen \& Hengge-Aronis, 1994). However, the evidence that the general stress response in B. subtilis is analogous to the $\sigma^{\mathrm{s}}$-dependent general stress and starvation response of $E$. coli, at least from a physiological point of view, is still preliminary (Engelmann et al., 1995; Hecker et al., 1996).

Since the mid-1980s we have been engaged in the functional analysis of stress proteins in B. subtilis. The powerful technique of high resolution two-dimensional (2-D) protein gel electrophoresis with its reflection of a very large set of the proteins synthesized by a bacterial cell has proved to be a very convenient method. The visual analysis of $2-\mathrm{D}$ protein gels combined with the identification of stress proteins by $\mathrm{N}$-terminal sequencing provided the first insights into the general stress response of B. subtilis (Hecker \& Völker, 1990; Völker et al., 1992, 1994). Besides the general stress proteins induced by various stress or starvation conditions, each single stimulus induces its specific set of stress-specific proteins. Heat stress, for instance, induces a small group of heat-shock proteins (class I heat-shock proteins, see Hecker et al., 1996, for review) as well as a 
Table 1. The three classes of heat-shock genes in B. subtilis

Heat-shock proteins of B. subtilis were characterized by 2-D protein gel electrophoresis and identified either by N-terminal sequencing of the protein or by disruption of the gene by insertion or deletion. Class I comprises heat-shock proteins, the induction of which requires CIRCE, the potential repressor $\mathrm{HrcA}$ and the vegetative sigma factor $\sigma^{\mathrm{A}}$. Heat-shock proteins belonging to class II require the stress-associated sigma factor $\sigma^{\mathrm{B}}$ for their induction by heat and other stresses. Heat-shock proteins which can be induced in the absence of $\sigma^{\mathrm{B}}$ or CIRCE were combined in class III. The various members of this group are most likely induced by heat or stress by different mechanisms. The promoters controlling the expression of genes encoding stress proteins, the molecular mass and isoelectric point estimated from migration in the 2-D gel (for a more detailed description, see VanBogelen et al., 1992), theoretical molecular mass and the isoelectric point calculated from the amino acid sequence (using the SWISS-PROT ProtParams tool) of the protein and the potential function of the protein are indicated. NA, not applicable.

\begin{tabular}{|c|c|c|c|c|c|c|c|c|c|}
\hline \multirow[t]{2}{*}{ Class } & \multirow[t]{2}{*}{ Protein } & \multirow[t]{2}{*}{ Identification } & \multirow[t]{2}{*}{ Promoter } & \multicolumn{2}{|c|}{$\begin{array}{l}\text { Estimated from } \\
\text { gel run }\end{array}$} & \multicolumn{2}{|c|}{$\begin{array}{c}\text { Calculated from } \\
\text { sequence } \dagger\end{array}$} & \multirow[t]{2}{*}{$\begin{array}{c}\text { Possible } \\
\text { function/similarity }\end{array}$} & \multirow[t]{2}{*}{ Reference } \\
\hline & & & & $\mathrm{pI}$ & $\begin{array}{l}\text { Size } \\
(\mathrm{kDa})\end{array}$ & $\mathrm{pI}$ & $\begin{array}{l}\text { Size } \\
(\mathrm{kDa})\end{array}$ & & \\
\hline \multirow[t]{4}{*}{ Class 1} & DnaK & $\mathrm{N}$ terminus & $\sigma^{\mathrm{A}}$ & 4.8 & 70 & 4.8 & 66 & Chaperone & Wetzstein et al. (1992) \\
\hline & GroEL & $\mathrm{N}$ terminus & $\sigma^{A}$ & 4.7 & 63 & 4.7 & 57 & Chaperone & Schmidt et al. (1992) \\
\hline & GroES & $\mathrm{N}$ terminus & $\sigma^{A}$ & $4 \cdot 6$ & 11 & 4.8 & 10 & Chaperone & Schmidt et al. (1992) \\
\hline & GrpE & $\mathrm{N}$ terminus & $\sigma^{\mathrm{A}}$ & $4 \cdot 5$ & 25 & 4.5 & 22 & Chaperone & Wetzstein et al. (1992) \\
\hline \multirow[t]{41}{*}{ Class 11} & $\mathrm{Ctc}$ & $\mathrm{N}$ terminus & $\sigma^{\mathrm{A}} \sigma^{\mathrm{B}}$ & $4 \cdot 5$ & 26 & $4 \cdot 4$ & 22 & Function unknown & $\begin{array}{l}\text { Moran et al. (1982); } \\
\text { Hilden et al. (1995) }\end{array}$ \\
\hline & GsiB & $N$ terminus & $\sigma^{\mathrm{B}}$ & $5 \cdot 2$ & 15 & $5 \cdot 3$ & 14 & Function unknown & Mueller et al. (1992) \\
\hline & GspA & $\mathrm{N}$ terminus & $\sigma^{\mathrm{B}}$ & $5 \cdot 2$ & 28 & $5 \cdot 2$ & 33 & Function unknown & $\begin{array}{l}\text { Glaser et al. (1991); } \\
\text { Antelmann et al. (1995) }\end{array}$ \\
\hline & GtaB & $\mathrm{N}$ terminus & $\sigma^{\mathrm{A}} \sigma^{\mathrm{B}}$ & $5 \cdot 1$ & 28 & $5 \cdot 1$ & 33 & $\begin{array}{l}\text { UDP-glucose } \\
\text { pyrophosphorylase }\end{array}$ & Varon et al. (1993) \\
\hline & $\mathrm{HSt} 23 / 23 \mathrm{r}$ & $\mathrm{N}$ terminus & $\sigma^{\mathrm{H}} \sigma^{\mathrm{B}}$ & $5 \cdot 3$ & 22 & $5 \cdot 4$ & 22 & $\begin{array}{l}\text { Similar to } \sigma^{54} \text { modulation } \\
\text { factors }\end{array}$ & $\begin{array}{l}\text { K. Drzewiecki and others, } \\
\text { personal communication }\end{array}$ \\
\hline & KatE & Deletion & $\sigma^{\mathrm{B}}$ & 6.1 & 72 & $5 \cdot 9$ & 78 & Catalase & Engelmann et al. $\langle 1995\rangle$ \\
\hline & RsbW & $\mathrm{N}$ terminus & $\sigma^{\mathrm{A}} \sigma^{\mathrm{B}}$ & 4.5 & 17 & 4.5 & 18 & Anti- $\sigma^{\mathrm{B}}$ & $\begin{array}{l}\text { Duncan et al. (1987); } \\
\text { Kalman et al. (1990) }\end{array}$ \\
\hline & $\mathrm{SigB}$ & $\mathrm{N}$ terminus & $\sigma^{\mathrm{A}} \sigma^{\mathrm{B}}$ & $5 \cdot 6$ & 31 & 5.5 & 30 & $\sigma^{\mathrm{B}}$ & $\begin{array}{l}\text { Duncan et at. (1987); } \\
\text { Kalman et al. }(1990)\end{array}$ \\
\hline & Gsp9 & $\mathrm{N}$ terminus & $\mathrm{NA}$ & $4 \cdot 5$ & 46 & $\mathrm{NA}$ & $\mathrm{NA}$ & Unknown & Völker et al. (1994) \\
\hline & Gsp13 & $\mathrm{N}$ terminus & NA & 6.6 & 12 & $\mathrm{NA}$ & $\mathrm{NA}$ & $\begin{array}{l}\text { Similar to Orf128 (B. } \\
\text { subtilis) }\end{array}$ & $\begin{array}{l}\text { H. Antelmann and others, } \\
\text { unpublished }\end{array}$ \\
\hline & Gsp16 & $\mathrm{N}$ terminus & $\mathrm{NA}$ & $4 \cdot 9$ & 27 & $\mathrm{NA}$ & $\mathrm{NA}$ & $\begin{array}{l}\text { Similar to OrfQ }\langle B . \\
\text { subtilis }\rangle\end{array}$ & $\begin{array}{l}\text { H. Antelmann and others, } \\
\text { unpublished }\end{array}$ \\
\hline & Gsp17o & $N$ terminus & $\mathrm{NA}$ & 4.9 & 13 & $\mathrm{NA}$ & $\mathrm{NA}$ & Unknown & Völker et al. (1994) \\
\hline & Gsp17m & $\mathrm{N}$ terminus & $\mathrm{NA}$ & 4.9 & 12 & $\mathrm{NA}$ & $\mathrm{NA}$ & Unknown & Völker et al. (1994) \\
\hline & Gsp18 & $\mathrm{N}$ terminus & $\mathrm{NA}$ & $4 \cdot 8$ & 19 & $\mathrm{NA}$ & $\mathrm{NA}$ & Similar to Yhbo $\langle E . c o l i\rangle$ & $\begin{array}{l}\text { H. Antelmann and others, } \\
\text { unpublished }\end{array}$ \\
\hline & Gsp200 & $\mathrm{N}$ terminus & $\mathrm{NA}$ & 4.7 & 18 & $\mathrm{NA}$ & $\mathrm{NA}$ & Unknown & Völker et al. (1994) \\
\hline & Gsp20m & $\mathrm{N}$ terminus & $\mathrm{NA}$ & $4 \cdot 6$ & 17 & $\mathrm{NA}$ & $\mathrm{NA}$ & Unknown & $\begin{array}{l}\text { H. Antelmann and others, } \\
\text { unpublished }\end{array}$ \\
\hline & Gsp20u & $\mathrm{N}$ terminus & $\mathrm{NA}$ & $4 \cdot 6$ & 16 & $\mathrm{NA}$ & $\mathrm{NA}$ & Unknown & $\begin{array}{l}\text { H. Antelmann and others, } \\
\text { unpublished }\end{array}$ \\
\hline & Gsp26 & $\mathrm{N}$ terminus & $\mathrm{NA}$ & $5 \cdot 2$ & 16 & $\mathrm{NA}$ & $\mathrm{NA}$ & Unknown & Völker et al. $\{1994\}$ \\
\hline & Gsp38 & $\mathrm{N}$ terminus & $\mathrm{NA}$ & $5 \cdot 0$ & 32 & $\mathrm{NA}$ & $\mathrm{NA}$ & Unknown & $\begin{array}{l}\text { H. Antelmann and others, } \\
\text { unpublished }\end{array}$ \\
\hline & Gsp80 & $\mathrm{N}$ terminus & $\mathrm{NA}$ & $4 \cdot 9$ & 28 & $\mathrm{NA}$ & $\mathrm{NA}$ & Unknown & $\begin{array}{l}\text { H. Antelmann and others, } \\
\text { unpublished }\end{array}$ \\
\hline & Gsp14 & ND & NA & $5 \cdot 2$ & 18 & $\mathrm{NA}$ & $\mathrm{NA}$ & Unknown & \\
\hline & Gsp17u & ND & NA & 4.9 & 11 & $\mathrm{NA}$ & $\mathrm{NA}$ & Unknown & \\
\hline & Gsp19 & ND & $\mathrm{NA}$ & 4.7 & 25 & $\mathrm{NA}$ & $\mathrm{NA}$ & Unknown & \\
\hline & Gsp61 & ND & $\mathrm{NA}$ & $6 \cdot 0$ & 105 & $\mathrm{NA}$ & $\mathrm{NA}$ & Unknown & \\
\hline & Gsp62 & ND & $\mathrm{NA}$ & 5.8 & 72 & $\mathrm{NA}$ & $\mathrm{NA}$ & Unknown & \\
\hline & Gsp64 & ND & $\mathrm{NA}$ & $7 \cdot 1$ & 58 & $\mathrm{NA}$ & $\mathrm{NA}$ & Unknown & \\
\hline & Gsp65 & ND & $\mathrm{NA}$ & 4.5 & 49 & $\mathrm{NA}$ & $\mathrm{NA}$ & Unknown & \\
\hline & Gsp66 & ND & $\mathrm{NA}$ & $6 \cdot 6$ & 44 & $\mathrm{NA}$ & NA & Unknown & \\
\hline & Gsp67 & ND & $\mathrm{NA}$ & 7.6 & 38 & $\mathrm{NA}$ & $\mathrm{NA}$ & Unknown & \\
\hline & Gsp68 & ND & $\mathrm{NA}$ & $4 \cdot 5$ & 38 & $\mathrm{NA}$ & $\mathrm{NA}$ & Unknown & \\
\hline & Gsp69 & ND & $\mathrm{NA}$ & 4.8 & 36 & $\mathrm{NA}$ & $\mathrm{NA}$ & Unknown & \\
\hline & Gsp70 & ND & $\mathrm{NA}$ & $5 \cdot 3$ & 31 & $\mathrm{NA}$ & $\mathrm{NA}$ & Unknown & \\
\hline & Gsp71 & $\mathrm{ND}$ & $\mathrm{NA}$ & 4.9 & 29 & $\mathrm{NA}$ & $\mathrm{NA}$ & Unknown & \\
\hline & Gsp73 & ND & $\mathrm{NA}$ & $5 \cdot 1$ & 28 & $\mathrm{NA}$ & $\mathrm{NA}$ & Unknown & \\
\hline & Gsp74 & ND & $\mathrm{NA}$ & 5.8 & 26 & $\mathrm{NA}$ & $\mathrm{NA}$ & Unknown & \\
\hline & Gsp75 & ND & $\mathrm{NA}$ & $4 \cdot 7$ & 19 & $\mathrm{NA}$ & $\mathrm{NA}$ & Unknown & \\
\hline & Gsp76 & ND & $\mathrm{NA}$ & 6.7 & 13 & $\mathrm{NA}$ & $\mathrm{NA}$ & Unknown & \\
\hline & Gsp77 & $\mathrm{ND}$ & $\mathrm{NA}$ & 6.5 & 13 & $\mathrm{NA}$ & $\mathrm{NA}$ & Unknown & \\
\hline & Gsp78 & $\mathrm{ND}$ & $\mathrm{NA}$ & 6.7 & 17 & $\mathrm{NA}$ & $\mathrm{NA}$ & Unknown & \\
\hline & Gsp79 & $\mathrm{ND}$ & $\mathrm{NA}$ & $7 \cdot 2$ & 16 & NA & $\mathrm{NA}$ & Unknown & \\
\hline & Gsp85 & ND & $\mathrm{NA}$ & 5.7 & 12 & $\mathrm{NA}$ & $\mathrm{NA}$ & Unknown & \\
\hline
\end{tabular}


Table 1. (cont.)

\begin{tabular}{|c|c|c|c|c|c|c|c|c|c|}
\hline \multirow[t]{2}{*}{ Class } & \multirow[t]{2}{*}{ Protein } & \multirow[t]{2}{*}{ Identification } & \multirow[t]{2}{*}{ Promoter } & \multicolumn{2}{|c|}{$\begin{array}{l}\text { Estimated from } \\
\text { gel run }\end{array}$} & \multicolumn{2}{|c|}{$\begin{array}{c}\text { Calculated from } \\
\text { sequence } \dagger\end{array}$} & \multirow[t]{2}{*}{$\begin{array}{c}\text { Possible } \\
\text { function/similarity }\end{array}$} & \multirow[t]{2}{*}{ Reference } \\
\hline & & & & $\mathrm{pI}$ & $\begin{array}{c}\text { Size } \\
\langle\mathrm{kDa})\end{array}$ & $\mathrm{pI}$ & $\begin{array}{c}\text { Size } \\
(\mathbf{k D a})\end{array}$ & & \\
\hline \multirow[t]{7}{*}{ Class III } & AhpC & $\mathrm{N}$ terminus & $\sigma^{A}$ & $4 \cdot 5$ & 19 & $4 \cdot 5$ & 21 & $\begin{array}{l}\text { Alkyl hydroperoxide } \\
\text { reductase C }\end{array}$ & $\begin{array}{l}\text { Hartford \& Dowds }(1994) \\
\text { Y. Kasahara, S. Nakai, H. } \\
\text { Yoshikawa \& N. } \\
\text { Ogasawara, GenBank no. D78193 }\end{array}$ \\
\hline & AhpF & Deletion & $\sigma^{A}$ & $4 \cdot 9$ & 52 & $4 \cdot 9$ & 55 & $\begin{array}{l}\text { Alkyl hydroperoxide } \\
\text { reductase } \mathrm{F}\end{array}$ & $\begin{array}{l}\text { Hartford \& Dowds }(1994) \\
\text { Y. Kasahara, S. Nakai, H. } \\
\text { Yoshikawa \& N. } \\
\text { Ogasawara, GenBank no. D78193 }\end{array}$ \\
\hline & ClpP & $\mathrm{N}$ terminus & $\sigma^{\mathrm{A}} \sigma^{\mathrm{B}}$ & $5 \cdot 1$ & 20 & $5 \cdot 2$ & 22 & $\begin{array}{l}\text { Proteolytic subunit of Clp } \\
\text { protease }\end{array}$ & $\begin{array}{l}\text { Völker et al. (1992); } \\
\text { U. Gerth and others, } \\
\text { personal communication }\end{array}$ \\
\hline & $\mathrm{ClpC}$ & Insertion & $\sigma^{\mathrm{A}} \sigma^{\mathrm{B}}$ & $7 \cdot 0$ & 80 & 5.8 & 90 & $\begin{array}{l}\text { ATPase subunit of Clp } \\
\text { protease }\end{array}$ & $\begin{array}{l}\text { Krüger } \text { et al. (1994); } \\
\text { Msadek et al. (1994) }\end{array}$ \\
\hline & $\operatorname{TrxA}$ & $\mathrm{N}$ terminus & $\sigma^{\mathrm{A}} \sigma^{\mathrm{B}}$ & $4 \cdot 5$ & 11 & $4 \cdot 3$ & 11 & Thioredoxin & $\begin{array}{l}\text { C. Scharf and others, } \\
\text { personal communication }\end{array}$ \\
\hline & Sod & $\mathrm{N}$ terminus & $?$ & $5 \cdot 0$ & 20 & $5 \cdot 1$ & 25 & $\begin{array}{l}\text { Superoxide dismutase } \\
\text { (YqgD) }\end{array}$ & $\begin{array}{l}\text { H. Antelmann and others, } \\
\text { unpublished }\end{array}$ \\
\hline & Gsp83 & ND & NA & $5 \cdot 4$ & 12 & $\mathrm{NA}$ & NA & Unknown & \\
\hline
\end{tabular}

very large group of general stress proteins. The majority of these general stress proteins absolutely require the alternative sigma factor $\sigma^{\mathrm{B}}$ for their induction by heat and other stresses (class II heat-shock proteins). However, a small group of stress proteins remain stress- and heat-inducible in a $\operatorname{sig} B$ mutant (class III heat-shock proteins).

The manual approach permitted only a very limited analysis of the large amount of information provided by high resolution 2-D protein gel electrophoresis and, therefore, we started a computer-aided analysis of 2-D images. The accompanying paper (Schmid et al., 1997) presents a catalogue of known vegetative proteins from our 2-D gels. Using these known vegetative proteins as marker spots, a 2-D master gel was established and the protein synthesis pattern during exponential growth under optimal laboratory conditions is described in the accompanying paper (Schmid et al., 1997). In this communication we present a thorough computer-aided analysis of the changes in protein synthesis patterns of $B$. subtilis following exposure to various stresses and starvation.

\section{METHODS}

Strains and culture conditions. The B. subtilis wild-type strains IS58 (trpC2 lys3; Smith et al., 1980) and 168 (trpC2, Anagnostopoulos $\&$ Spizizen, 1961) the $\operatorname{sig} B$ mutant strains $B$. subtilis BGH1 (trpC2 lys 3 sigB : : HindIII-EcoRV : : cat; Maul et al., 1995) and ML6 (trpC2 sigBA::HindIII-EcoRV::cat; Igo et al., 1987) and the $r s b W$ mutant strain B. subtilis BSA115 (rsbU::kan, $\mathrm{P}_{\mathrm{B}} \Delta 28:: \mathrm{P}_{\mathrm{SPAC}}$ rsbW313 pTet-1 SP $\beta c t c:$ lacZ; Völker et al., 1995a) were cultivated in a synthetic medium described previously (Stülke et al., 1993). Bacteria were grown to a density of $5 \times 10^{7}$ cells $(\mathrm{ml} \text { culture })^{-1}\left(\mathrm{OD}_{500}=0.4\right)$ and the stresses were imposed according to the following schemes: heat shock - the culture was shifted from $37^{\circ} \mathrm{C}$ to $48^{\circ} \mathrm{C}$; salt stress - solid sodium chloride was added to a final concentration of $4 \%(\mathrm{w} / \mathrm{v})$; oxidative stress - cells were treated with hydrogen peroxide in a final sub-lethal concentration of $0.0002 \%(\mathrm{v} / \mathrm{v})$ (compare Engelmann et al., 1995); ethanol stress - ethanol was added to a final concentration of $4 \%$ $(\mathrm{v} / \mathrm{v})$. Bacterial culture $(2 \mathrm{ml})$ was labelled for $3 \mathrm{~min}$ with $5 \mu \mathrm{Ci}(185 \mathrm{kBq}) \mathrm{L}-\left[{ }^{35} \mathrm{~S}\right]$ methionine $\mathrm{ml}^{-1}$ during exponential growth immediately before (control) and 5, 10 and $20 \mathrm{~min}$ after stress. Glucose or phosphate starvation were triggered by cultivating the bacteria with growth-limiting amounts of $0.05 \%(\mathrm{w} / \mathrm{v})$ glucose or $0.3 \mathrm{mM}$ potassium phosphate. Samples were labelled and harvested either during growth or after the exhaustion of glucose or phosphate.

Analysis of radiolabelled 2-D protein gels. The $\mathrm{L}-\left[{ }^{35} \mathrm{~S}\right]$ methionine-labelled samples for analytical 2-D electrophoresis were prepared and separated as described in the accompanying paper (Schmid et al., 1997). Crude protein extracts containing $10^{6} \mathrm{c} . \mathrm{p} . \mathrm{m}$. were loaded onto isoelectric focusing gels for 2-D gel electrophoresis. After drying, the 2-D gels, with the radioactively labelled proteins, were exposed to phosphor screens (Molecular Dynamics Storage Phosphor Screen $20 \times 25 \mathrm{~cm}$ ) for $24 \mathrm{~h}$ and scanned with a PhosphorImager SI (Molecular Dynamics) at a resolution of $200 \mu \mathrm{m}$. The raw gel images were transferred to a Sun-Sparc workstation and analysed with the PDI software package PDQuest version 5.0. For matching and quantification, the raw images were smoothed to remove the noise, background was subtracted and spots were detected in uncalibrated quantification mode (for more detailed information, see the user's guide of PDQuest version 5.0). For calculation of the relative spot quantity, the total activity detected within the gel was set to $100 \%$ and the relative synthesis rates of individual spots were calculated and expressed as:

$\left(\frac{\text { Radioactivity of individual spot }}{\text { Radioactivity of whole gel }} \times 100\right) \%$

All experiments were performed at least twice. The results of both parallels were analysed with the built-in Student's $t$-test (confidence level 0.05 ) of the PDI package which ensured that 

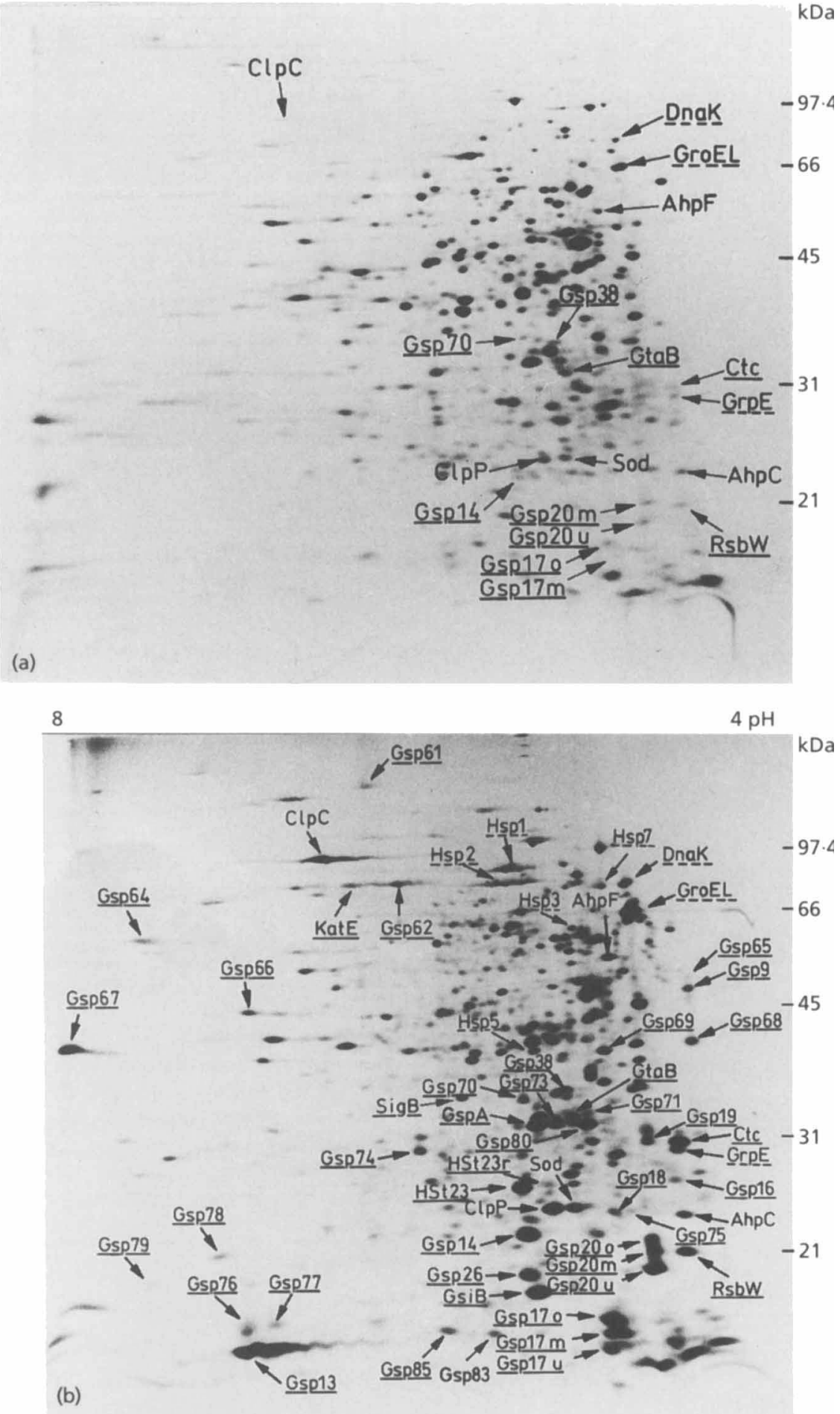

Fig. 1. For legend see facing page.

only significant changes in the density of protein spots were taken into consideration.

Computer-accessible protein data. All the protein data described in this communication can be accessed in 'Sub2D the 2-D protein index of Bacillus subtilis' via the World Wide Web using a WWW browser like Mosaic or Netscape under the URL http://www.uni-greifswald.de/aghecker/ index.html

\section{RESULTS}

\section{General description of stress proteins in B. subtilis}

The 2-D gel electrophoresis of $\mathrm{L}-\left[{ }^{35} \mathrm{~S}\right]$ methioninelabelled crude protein extracts from $B$. subtilis permitted the separation and analysis of about 600 distinct protein spots. A computer-aided analysis and comparison of the protein synthesis pattern of exponentially growing and 


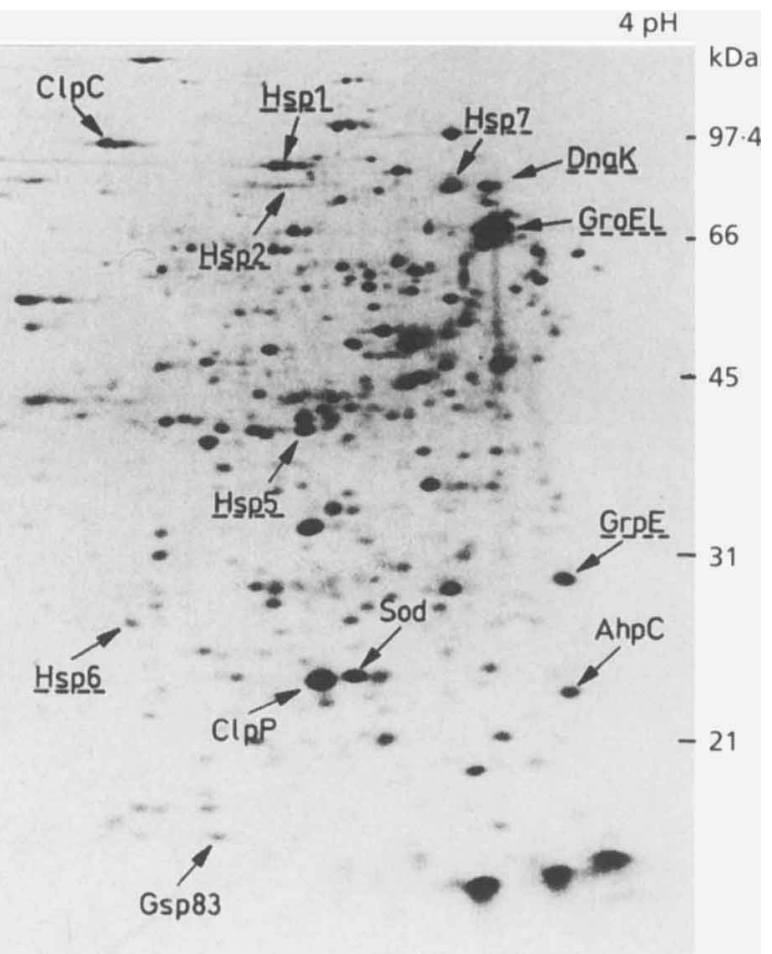

\begin{abstract}
Fig. 1. 2-D pattern of radiolabelled proteins from $B$. subtilis wild-type $1558(a, b)$ and its isogenic sigB-mutant BGH1 (c). Bacteria were grown in a synthetic medium and labelled with L- $\left.{ }^{35} \mathrm{~S}\right] \mathrm{methionine}$ for $3 \mathrm{~min}$ either during exponential growth (a) or heat shock $\left(5 \mathrm{~min}, 48^{\circ} \mathrm{C} ; \mathrm{b}, \mathrm{c}\right)$. Class I heat-shock proteins [heat-specific stress proteins (Hsps)] are underlined with dashed lines. Class II heat-shock proteins [sigB-dependent general stress proteins (Gsps)] are underlined. Class III heat-shock proteins [sigB- and CIRCEindependent general stress proteins (Gsps)] are not underlined.
\end{abstract}

stressed cells allowed us to distinguish five subsets of proteins according to their response to growthrestricting factors (see also Schmid et al., 1997): (I) proteins synthesized de novo in response to the stress factor; (II) proteins synthesized at an enhanced rate; (III) proteins whose synthesis rates remained unchanged; (IV) proteins synthesized at a reduced rate; and $(\mathrm{V})$ proteins whose synthesis was totally blocked.

In previous investigations two major groups of stress proteins have been described by a simple visual interpretation of 2-D protein gels. The first group of proteins was induced by a whole range of stimuli including heat and salt stress, or glucose, oxygen or phosphate starvation, whereas the second group was induced by a single stimulus only (Hecker \& Völker, 1990). This preliminary classification into stress-specific proteins and general stress proteins induced by several stimuli was confirmed by this global and more detailed computer-aided interpretation of the 2 -D protein gels (see also Table 1).

In the case of heat stress a small group of 10 heat-specific stress proteins (Hsps 1-3 and 5-7, DnaK, GroEL, GroES and GrpE) as well as a very large group of nearly 50 general stress proteins could be described (Figs 1 and 2). Among the general stress proteins 42 required the stressassociated sigma factor $\sigma^{\mathrm{B}}$ for induction by heat shock (class II heat-shock proteins), whereas at least seven proteins remained heat-inducible even in the absence of $\sigma^{\mathrm{B}}$ (Figs 1 and 2). These proteins were called $\sigma^{\mathrm{B}}$ independent general stress proteins (class III heat-shock proteins). The combination of 2-D protein gel electrophoresis with $\mathrm{N}$-terminal sequencing allowed the identification of a number of stress proteins, as illustrated in
Table 1 for general and heat-specific stress proteins. Twenty $\sigma^{\mathrm{B}}$-dependent and six $\sigma^{\mathrm{B}}$-independent general stress proteins, which include the stress-inducible proteases/chaperones ClpP and $\mathrm{ClpC}$ as well as AhpC, AhpF, Sod and TrxA were identified on 2-D gels (Table 1, Figs 1 and 2).

\section{Computer-aided interpretation of 2-D protein gels}

The protein synthesis patterns of exponentially growing cells and bacteria exposed to various stress and starvation conditions were matched and analysed by computer-aided image processing of high resolution 2-D polyacrylamide gels using the PDI computer package PDQuest. Such an approach allowed a direct evaluation of the synthesis rates of single proteins under different physiological conditions. A comparison of the relative synthesis rates of stress proteins and vegetative proteins showed that only a few of the stress proteins, especially GroEL, were synthesized at a high rate during growth (Fig. 3). However, since the relative synthesis rate of the vegetative proteins dropped during stress and starvation from $93 \%$ to about $70-45 \%$ (Fig. 4 ; Schmid et al., 1997) and the synthesis of the stress proteins was dramatically stimulated under the same conditions, the stress proteins contributed considerably to the residual protein synthesis of the cell. The relative synthesis rate of $\sigma^{\mathrm{B}}$ dependent general stress proteins increased from $1 \%$ to about $25-36 \%$ in response to heat, salt or ethanol stress, or after glucose starvation, but remained very low in response to $\mathrm{H}_{2} \mathrm{O}_{2}$ and the level of $\sigma^{\mathrm{B}}$-independent general stress proteins increased approximately three- to fourfold during stress (Fig. 4). For some of the $\sigma^{\mathrm{B}}$. dependent general stress proteins, especially GsiB and 

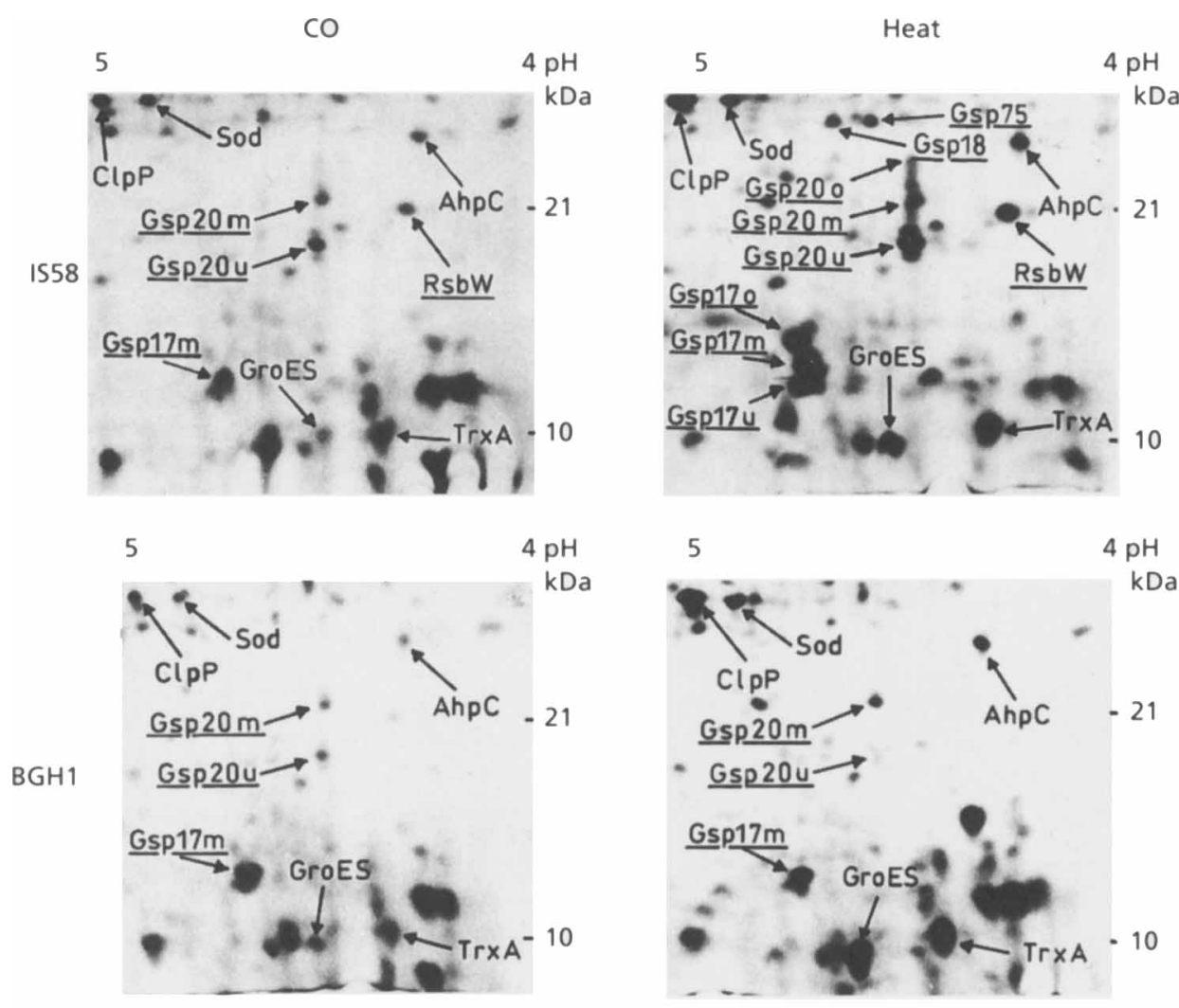

Fig. 2. Small, acidic stress proteins of B. subtilis. B. subtilis wild-type (IS58) and the sigB mutant (BGH1) were labelled with $\mathrm{L}-\left[{ }^{35} \mathrm{~S}\right]$ methionine for $3 \mathrm{~min}$ either during exponential growth (CO) or heat shock $\left(5 \mathrm{~min}\right.$, $48^{\circ} \mathrm{C}$; Heat). Crude radiolabelled protein extracts were separated with the Millipore Investigator system for 2-D electrophoresis using $12 \%$ polyacrylamide gels which facilitated a better resolution of the small stress proteins. The sector of the gel shown displays the molecular mass range $8-22 \mathrm{kDa}$ and the pl range 4-5. Class III heat-shock proteins are indicated (not underlined) and class II heat-shock proteins are underlined.

GspA, the synthesis rate and the level of the proteins increased remarkably during stress, placing them among the cell proteins with the highest synthesis rates (data not shown).

However, it should be mentioned that the extent of the $\sigma^{\mathrm{B}}$-dependent stress response may vary with the specific strains used in the analysis. For instance, we found that B. subtilis 168 displayed a less pronounced induction of $\sigma^{\mathrm{B}}$-dependent stress genes in response to heat shock than B. subtilis IS58 used in this study (data not shown).

\section{$\sigma^{B}$ is the master regulator of the $\sigma^{\mathrm{B}}$-dependent stress regulon}

$\sigma^{\mathrm{B}}$ is required for the induction of at least 42 of the 50 general stress proteins described so far (Fig. 1; Völker $e t$ al., 1994). A great body of genetic and biochemical data provided evidence that controlling the activity of $\sigma^{\mathrm{B}}$ is the critical step in the expression of $\sigma^{\mathrm{B}}$-dependent genes. If the activity of $\sigma^{\mathrm{B}}$ is indeed the only factor regulating the expression of the $\sigma^{\mathrm{B}}$-dependent general stress proteins, then the synthesis of active $\sigma^{\mathrm{B}}$ should induce the regulon. In the $B$. subtilis strain BSA115 a $\operatorname{sig} B$ operon with a null mutation in the primary negative regulator RsbW (Benson \& Haldenwang, 1992; Boylan et al., 1992) is placed under the control of the IPTGinducible promoter $\mathrm{P}_{\mathrm{SPAC}}$. In this strain the addition of IPTG led to the production of active $\sigma^{\mathrm{B}}$ and the induction of $\sigma^{\mathrm{B}}$-dependent general stress proteins in the absence of stress or starvation (Fig. 5). However, compared to the stress induction in the wild-type strain, the absolute level of induction seemed to be rather low, which might be explained by the low level expression of $\sigma^{\mathrm{B}}$ in this strain (Figs 3 and 5 ; Benson \& Haldenwang, 1993; Völker et al., 1995a).

\section{Identification of subgroups in the $\sigma^{\mathrm{B}}$-dependent and $\sigma^{\mathrm{B}}$-independent general stress proteins}

The availability of relative protein synthesis rates for a large number of individual proteins under various growth-restricting conditions allowed the description of subgroups of stress proteins (and genes) which in addition to the master regulator might be controlled by other regulatory elements.

In the case of the $\sigma^{\mathrm{B}}$-dependent stress regulon, a few subgroups could be classified. Some proteins could not be detected on 2-D gels of protein extracts from growing 
(a) Class I- heat-specific stress proteins
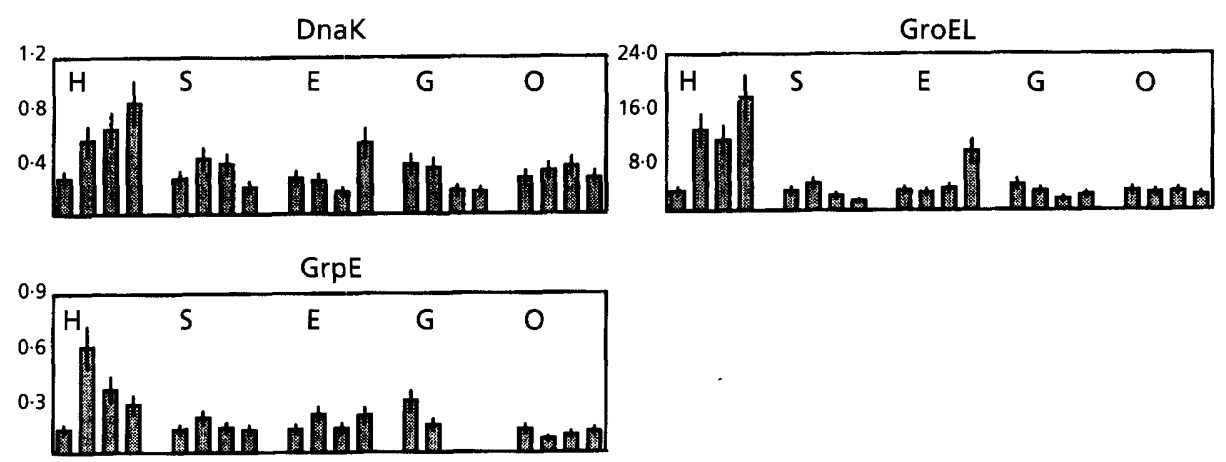

(b) Class II-sigB-dependent general stress proteins
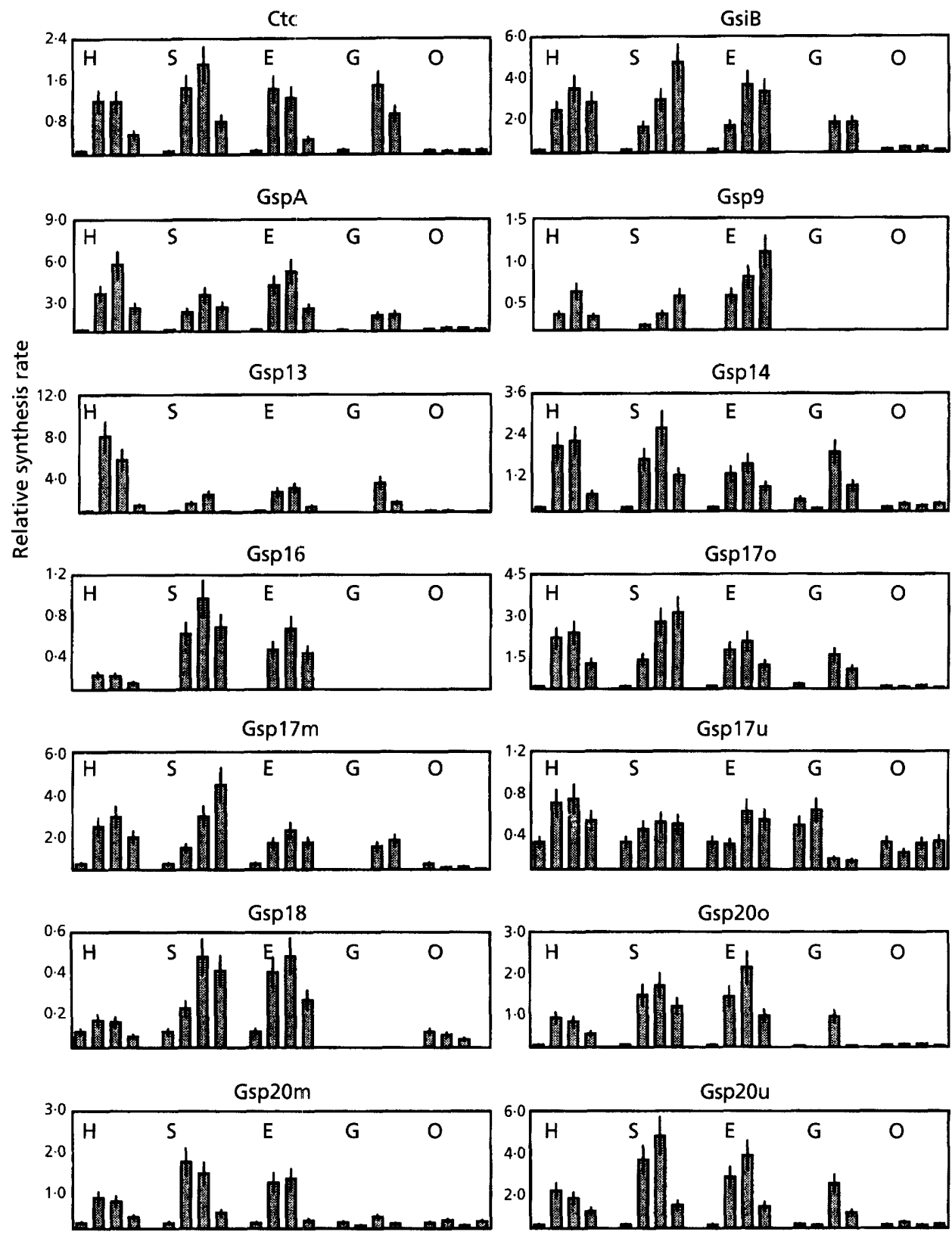

Fig. 3. For legend see p. 1007. 

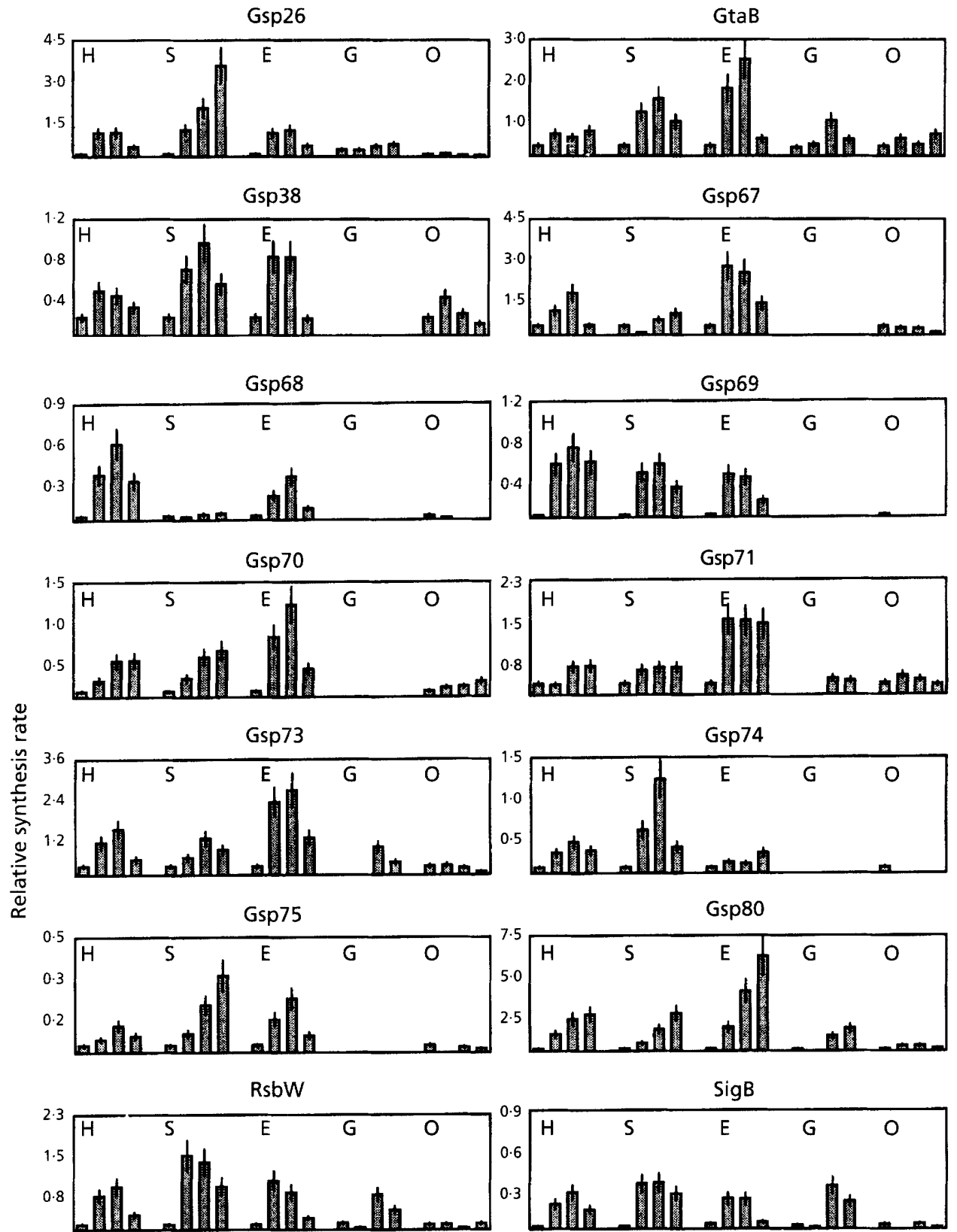

(c) Class Ila - strong induction during starvation for glucose
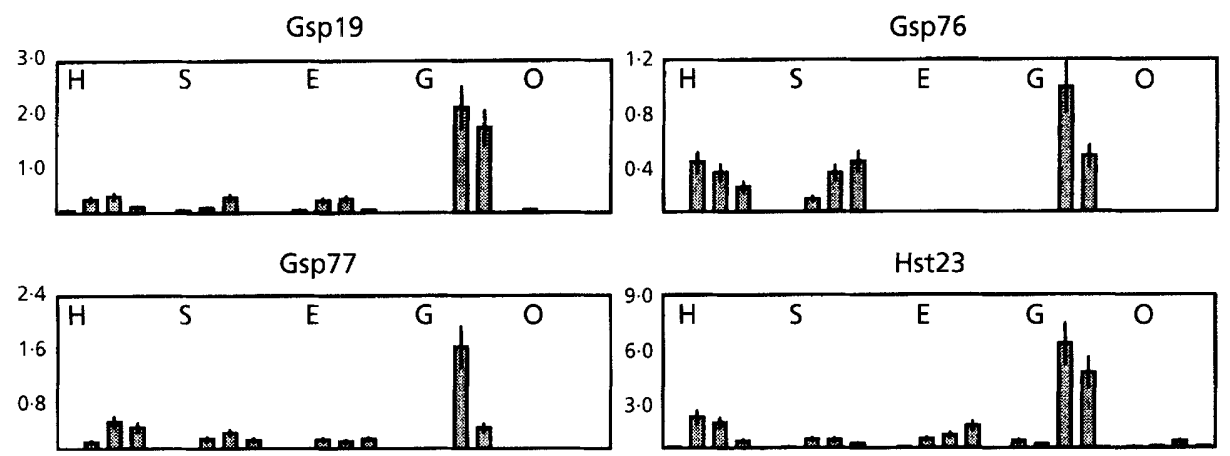

Fig. 3. For legend see facing page. 


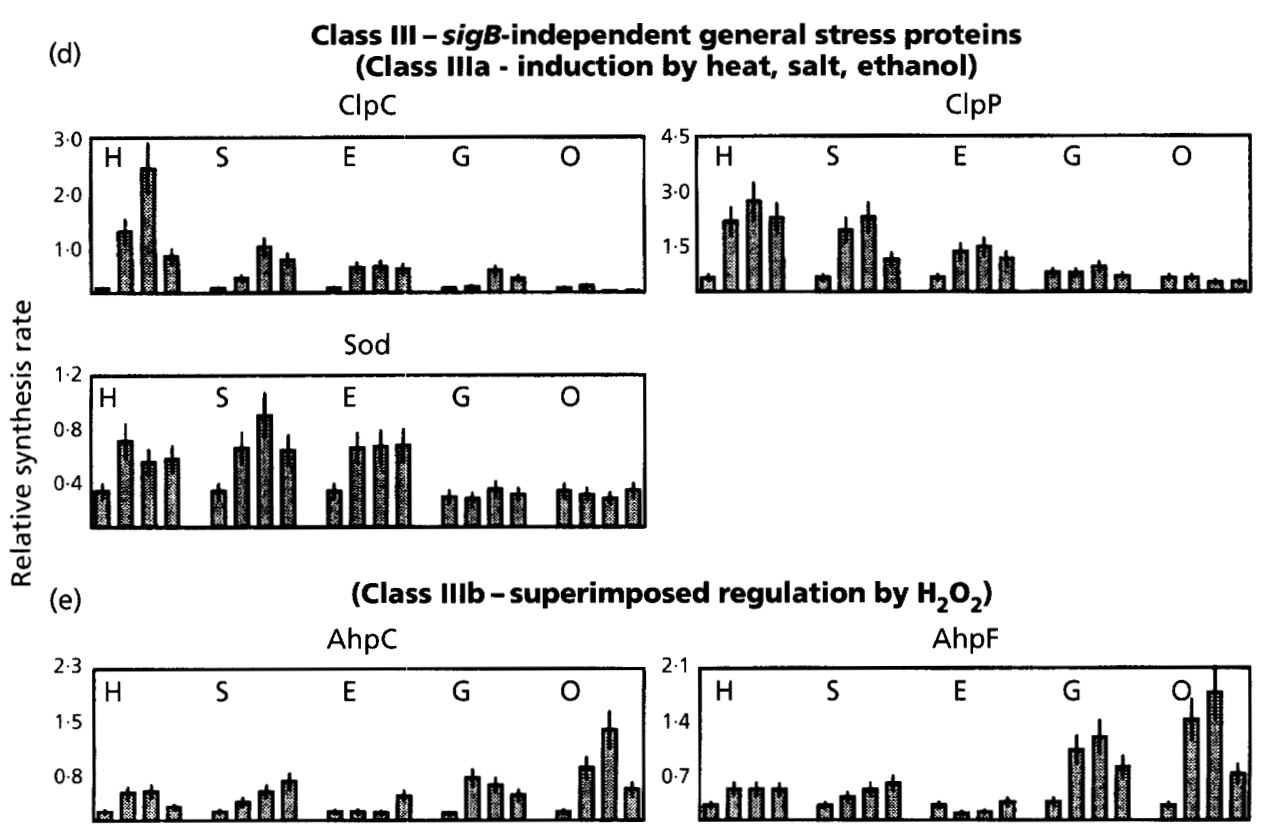

Fig. 3. Quantitative analysis of the induction of heat-shock proteins. (a) Class $I_{t}$ heat-specific stress proteins; (b) class II, sigB-dependent general stress proteins; (c) class $1 \mathrm{la}$, sigB-dependent general stress proteins which show a glucosestarvation-dependent hyperinduction; (d) class IIla, sigB-independent general stress proteins showing no induction during oxidative stress; (e) class $\mathrm{Illb}$, sigB-independent general stress proteins showing a hyperinduction by hydrogen peroxide. All diagrams contain five groups of columns: $H$, heat shock; $S$, salt stress; $E$, ethanol stress; $G$, glucose starvation; O, oxidative stress. Each group comprises four columns which represent the relative synthesis rate before stress (first column - control) and 5, 10 and 20 min after stress (second, third and fourth columns, respectively). For the analysis of glucose starvation, samples were taken during exponential growth, during the transient phase, and 60 or $90 \mathrm{~min}$ after entry into the stationary phase (for details see Fig. 2a of the accompanying paper, Schmid et al., 1997). Error bars represent the mean SD.

cells but were strongly induced by stress or starvation. Genes which have only one $\sigma^{\mathrm{B}}$-dependent promoter and thereby are exclusively controlled by $\sigma^{\mathrm{B}}$, such as gsiB (Maul et al., 1995) or gspA (Antelmann et al., 1995), encode proteins belonging to this subgroup. Gsp9, 13, $16,17 \mathrm{o}, 20 \mathrm{o}$ and 80 seemed to fall into this subgroup of $\sigma^{\mathrm{B}}$-dependent Gsps too (for synthesis data, see Fig. $3 \mathrm{~b}$; for 2-D gels, see Fig. 6).

For another group of proteins, a low level of synthesis during growth which was induced by stress in a $\sigma^{\mathrm{B}}$. dependent manner was apparent. Besides the $\sigma^{\mathrm{B}}$-dependent promoter, the corresponding genes also contain a second $\sigma^{\mathrm{A}}$-dependent promoter (gtaB, Varon et al., 1993; ctc, Tatti et al., 1985, and Hilden et al., 1995; rsbW, Boylan et al., 1992). For this group the stress induction ratio depended on the strength of the second promoter. In addition to GtaB, Ctc and RsbW, Gsp14, $17 \mathrm{~m}, 18,20 \mathrm{~m}, 33,38,67,71,74$ and 75 were also allocated to this group. The basal level expression from potential $\sigma^{A}$-dependent promoters varied considerably from very weak, as in the case of $c t c$, to rather high, as for $g t a b$.

Some of the $\sigma^{\mathrm{B}}$-dependent proteins described here appeared to display an atypically strong induction by ethanol stress (Gsp9, 33, 67, 70, 71, 80 and GtaB) or salt stress (RsbW, Gsp16, 17o, 17m, 26, 74) or both (Gsp18, 20o, 20u) or heat stress (Gsp13, 68) (for 2-D gels, see Fig. $1 \mathrm{a}$ and Fig. 6; for protein synthesis data, see Fig. 3b). The basis for this atypical induction remains to be elucidated.

A small group of $\sigma^{\mathrm{B}}$-dependent stress proteins (HSt23, 23r, Gsp19, 76, 77) displayed a tremendous induction under glucose starvation (Figs $3 \mathrm{c}$ and $6 \mathrm{c}$ ), besides the usual stress induction pattern, and HSt 23 and $23 \mathrm{r}$ also displayed an induction under amino acid starvation. $\sigma^{\mathrm{B}}$ is not activated by amino acid starvation and at least for HSt23 this superimposed regulation by glucose and amino acid limitation was $\sigma^{\mathrm{B}}$-independent $(\mathrm{K}$. Drzewiecki and others, personal communication). Only three $\sigma^{\mathrm{B}}$-dependent general stress proteins (Gsp38, 70, 71) seemed to be induced by oxidative stress (Fig. 3), indicating a regulation by oxygen radicals in addition to the $\sigma^{\mathrm{B}}$-dependent regulation.

According to their induction pattern, the $\sigma^{\mathrm{B}}$-independent general stress proteins can be divided into at least two subgroups. The synthesis of $\mathrm{ClpC}$ was very low during growth, strongly induced by stress and to a lesser extent by glucose limitation, and a mutation in $\operatorname{sig} B$ did not reduce the stress induction of $\mathrm{ClpC}$ (Figs 1 and 3). Because of the rather high basal level of expression during growth, the induction of $c l p P$ by stress was less pronounced and although ClpP was still induced in a $\sigma^{\mathrm{B}}$ 
(a)

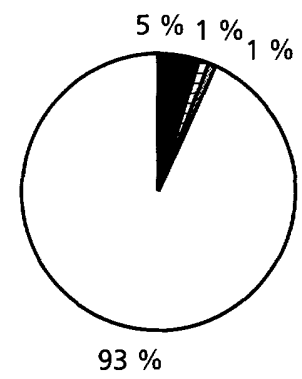

(d)

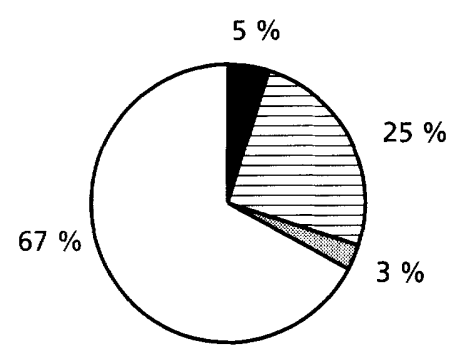

(b)

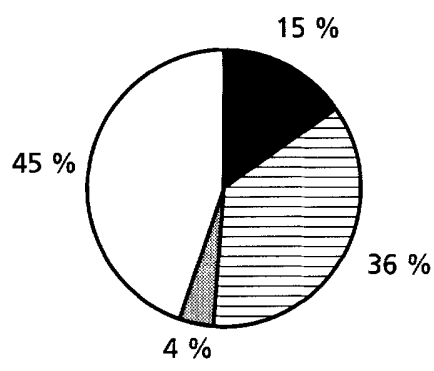

(e)

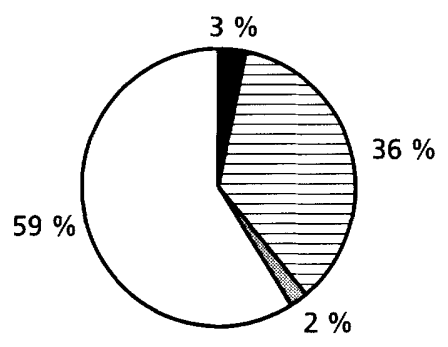

(c)

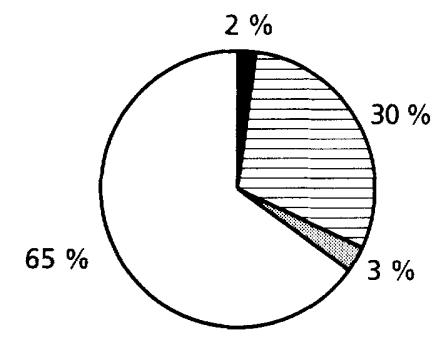

(f)

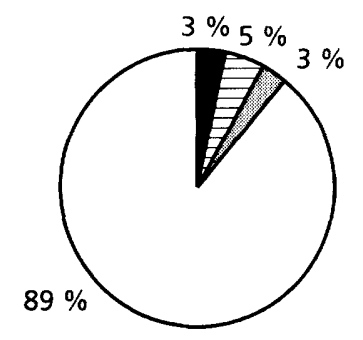

Fig. 4. Distribution of methionine incorporation among the different protein classes during (a) exponential growth and after exposure to (b) 5 min heat shock, (c) glucose starvation, (d) 5 min salt stress, (e) 5 min ethanol stress and (f) 5 min hydrogen peroxide. $\square$, Hsps; 目, sigB-dependent Gsps; 圈, sigB-independent Gsps; $\square$, others.

mutant, the total induction was lower than in the wildtype, indicating an involvement of $\sigma^{\mathrm{B}}$ in the stress induction of ClpP (Figs 1 and 3; U. Gerth and others, personal communication).

$\mathrm{AhpC}$ and $\mathrm{AhpF}$ displayed another induction pattern with a superimposed induction by $\mathrm{H}_{2} \mathrm{O}_{2}$ (Fig. 6e) and a moderate induction by glucose starvation. Both proteins, as well as Sod, showed a distinct synthesis rate during growth which was induced only threefold by heat or salt stress (Fig. 3d, e).

\section{Stress- or starvation-specific proteins in B. subtilis}

Besides general stress proteins, heat shock, salt and oxidative stress, and glucose and phosphate starvation induced their own specific set of proteins (Fig. 6) which may provide a specific protection against the respective stress and not against any other. We failed to detect such specific stress proteins after treatment with ethanol. All these conditions except oxidative stress also induced the $\sigma^{\mathrm{B}}$-dependent general stress response which is not indicated in Fig. 6. In previous studies a few stressspecific proteins were identified for phosphate starvation [the high-affinity phosphate-binding protein $\mathrm{YzmB}$ (Psi1-3, SWISS-PROT accession no. P46338; Eymann et al., 1996)], for oxidative stress [KatA, MrgA, AhpC and AhpF (Fig. 6; S. Engelmann, personal communication) (AhpC and AhpF are mentioned here although they were also induced by other stresses such as heat or salt stress because they displayed a particularly strong induction by oxidative stress)] and for heat stress [chaperones GroEL, GroES, DnaK, GrpE (Völker et al., 1992)]. The expression of heat-specific stress proteins DnaK, GroEL and GrpE is controlled by the concerted action of the CIRCE element (Zuber \& Schumann, 1994 ) and the negative regulator HrcA (Yuan \& Wang, 1995a, b; Schulz et al., 1995). Western blot analysis with GroEL-specific antibodies confirmed a fast and strong increase in the amount of GroEL after heat shock, but revealed also a slow, continuous accumulation of GroEL after treatment with $4 \%$ ethanol. Ethanol stress might generate the same signal as heat shock and allow the continuous synthesis of GroEL. Heat-shock-specific proteins Hsp1 and Hsp2 seemed to be subject to a different regulation because a mutation in hrcA (orf39) increased GroEL synthesis sixfold during growth compared to the wild-type but did not influence the levels of Hsp1 or Hsp2 (data not shown).

\section{DISCUSSION}

The combination of high resolution 2-D PAGE (including the identification of proteins on 2-D gels) with computer-aided image processing of 2-D gels loaded with $\mathrm{L}-\left[{ }^{35} \mathrm{~S}\right]$ methionine-labelled protein extracts is a very powerful tool for microbial physiology in general. 
In the preceding paper (Schmid et al., 1997) the first steps to establish a database for vegetative proteins of $B$. subtilis are presented which are supplemented by this study on B. subtilis stress proteins. About 60 proteins of $B$. subtilis have been identified on 2-D polyacrylamide gels so far (see also Graumann et al., 1996; Lottering \& Streips, 1995; Miller et al., 1991; Schmid et al., 1997; H. Antelmann and others, unpublished). With the resolution of more than 600 proteins whose synthesis rates can be measured and compared by this computer-aided analysis under quite different physiological conditions, comprehensive information on the global regulation of gene expression of the whole cell will be available.

A similar approach has been successfully employed for E. coli by F. C. Neidhardt and co-workers since the mid1970s (VanBogelen et al., 1992, 1996), and later related studies were carried out on Salmonella typhimurium (Abshire \& Neidhardt, 1993), Streptomyces coelicolor (Puglia et al., 1995), Pseudomonas putida (Lupi et al., 1995) and other bacteria.

In this study computer-aided analysis of 2-D protein gels was used for a comprehensive description of the stress response in $B$. subtilis. Both general or unspecific proteins induced by several stresses as well as specific stress proteins were characterized. In Fig. 6 several stress-specific proteins induced either by heat, salt or oxidative stress, or by phosphate or glucose starvation are indicated. These stress-specific proteins induced by one stress may have a protective function against a single stress only (i) to counteract the stress or (ii) to adapt to the stress action or (iii) to repair damage induced by the stress. For example, heat-specific chaperones, such as the GroESL or DnaK machine (Fig. 6e), are able to assist proper protein folding, the oxidative-stress-specific catalase A, the DNA-binding protein MrgA, or alkyl hydroperoxide reductase (Fig. 6g, Antelmann et al., 1996; S. Engelmann and others, personal communication) protect the cell against a lethal oxidative challenge and the high-affinity phosphatebinding protein (YzmB, Psi1-3, Fig. 6d, Eymann et al., 1996) allows the phosphate-starved cell to be more competitive in taking up phosphate sources at extremely low phosphate concentrations. These results also provide premature information on the number of genes involved in these single regulons or stimulons. According to this preliminary and global view, the phosphate stimulon seems to contain many different genes (Eymann et al., 1996), but only a few genes might be expressed in response to salt stress or heat stress, at least under the experimental conditions used in this study. However, this study only provides a rough estimation which does not involve all proteins. Among the salt-specific stress proteins, for instance, a whole set of membrane-bound transport proteins which were not analysed in this study might be expected.

One of the very early responses of a bacterial cell to the transition from a growing to a non-growing state is the most dramatic induction of a characteristic set of protein in response to diverse stresses or starvation, in contrast to stress-specific proteins. These proteins may provide a rather unspecific protective function under stress regardless of the specific stress factor and are therefore referred to as general stress proteins (Hecker \& Völker, 1990). Our computer-aided study argues that the general stress response may be very important for the cell during stress because these cells devote up to $40 \%$ of their translational capacity to the synthesis of general stress proteins. Therefore, from a physiological point of view it seems to be a very promising goal to study this immense general stress response in greater detail, which may be the most voluminous regulon or stimulon response of a non-growing but non-sporulating cell. In this study about 50 general stress proteins were described, the majority of which belong to the very large $\sigma^{\mathrm{B}}$-dependent stationary phase or stress regulon (Boylan et al., 1993; Völker et al., 1994; Hecker et al., 1996).

Recent studies provide new information that different extracellular stimuli increase the expression of $\sigma^{\mathrm{B}}$ dependent genes via two different pathways (Völker et al., 1995b; Wise \& Price, 1995). Nutrient limitations activate $\sigma^{\mathrm{B}}$ via a decrease in the intracellular ATP level (Alper et al., 1996; Maul et al., 1995; Völker et al., $1995 \mathrm{~b}$ ), whereas the activation of $\sigma^{\mathrm{B}}$ in response to stress requires at least three more proteins encoded by the eight-gene sigB operon (Dufour et al., 1996; Völker et al., 1995b; Wise \& Price, 1995; Yang et al., 1996). In this paper we present evidence that the activation of $\sigma^{\mathrm{B}}$ by the various extracellular signals is sufficient for the induction of the whole set of $\sigma^{\mathrm{B}}$-dependent general stress proteins. In this respect, the $\sigma^{\mathrm{B}}$-dependent stress proteins are really general stress proteins since a single regulator $\left(\sigma^{\mathrm{B}}\right)$ enhances the expression of the corresponding genes in response to quite different stimuli.

The combination of the computer-aided 2-D protein analysis with $\mathrm{N}$-terminal sequencing of proteins also allowed us to distinguish at least three subgroups of $\sigma^{\mathrm{B}}$ dependent genes: (I) genes which depend solely on $\sigma^{\mathrm{B}}$ (gsiB, gspA, katE); (II) genes which contain in addition a vegetative promoter, $\mathrm{P}_{\mathrm{A}}$, that contributes to the basal expression level in growing cells (ctc, gtaB, $r s b W)$; and (III) genes containing target sequences for other regulatory proteins or one (or more) additional promoter(s) which may also be stress-inducible or controlled by other extracellular signals. At least four proteins (HSt23, Gsp19, 76, 77) which show the typical $\sigma^{\mathrm{B}}$-dependent stress induction pattern are very strongly induced by glucose starvation, even stronger than by the $\sigma^{\mathrm{B}}$-related regulation alone. The investigation of the mechanism responsible for this particularly strong induction will provide insights into the interaction between the stress regulon and other regulons of a $B$. subtilis cell.

The products of only some of the genes analysed and allocated to the $\sigma^{\mathrm{B}}$-independent general stress group could be identified by our 2-D protein gel electrophoresis study (class III heat-shock proteins; ClpC, ClpP, Sod, AhpC, AhpF; see Hecker et al., 1996, for review). Among others, Lon, FtsH and ClpX still have to be located on the gels. Even this relatively small group of 
8

$4 \mathrm{pH}$

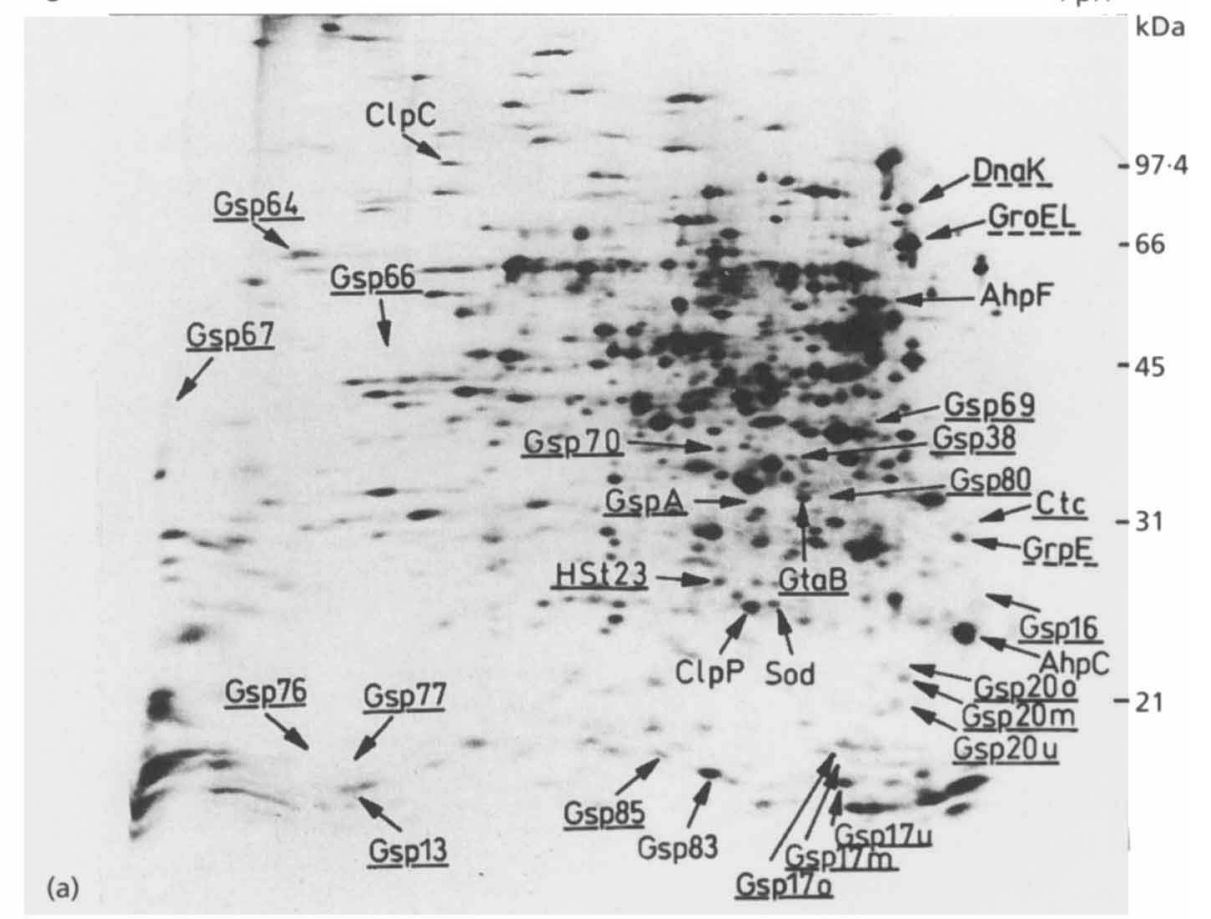

8

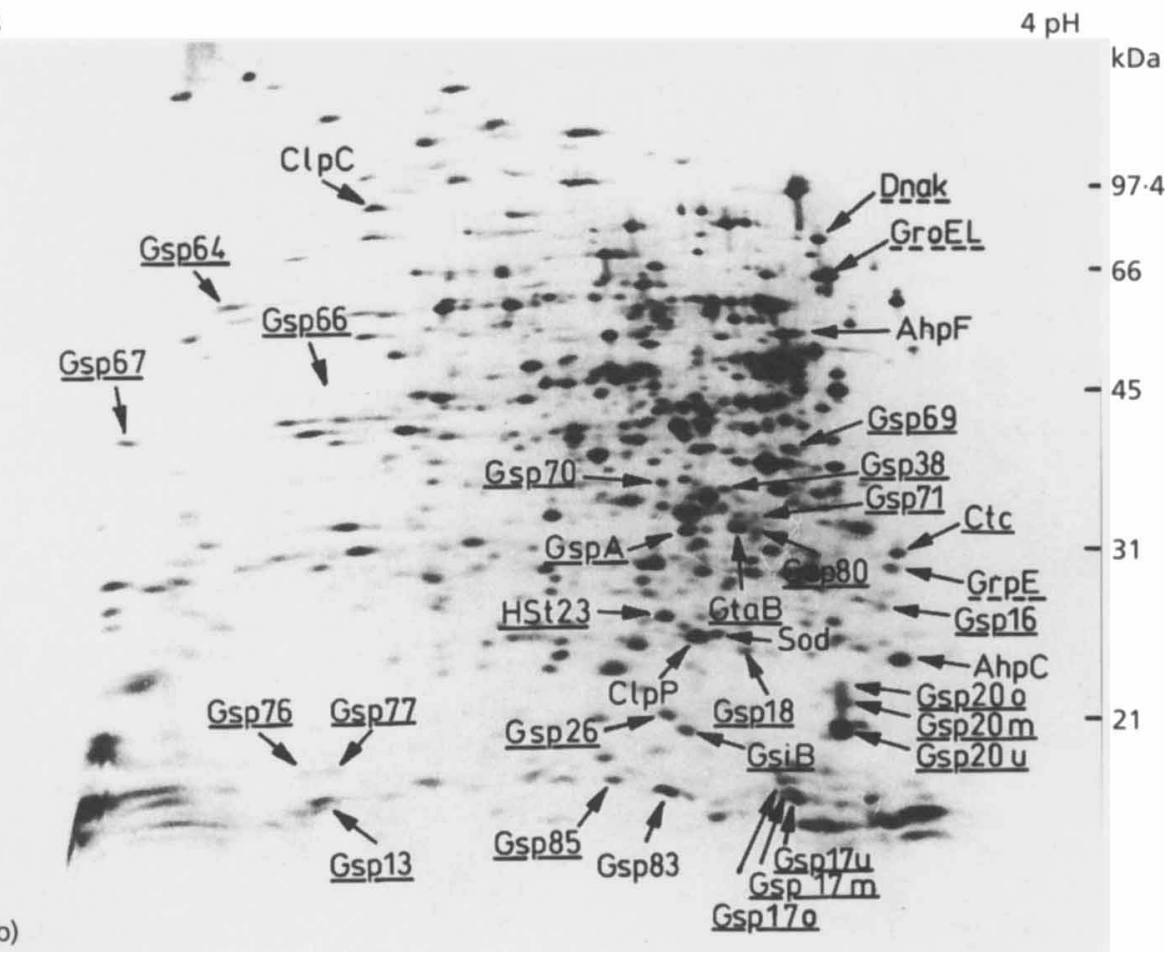

Fig. 5. For legend see facing page.

general stress proteins comprising stress-inducible proteases, chaperones, etc., can be divided into subgroups. A few genes supposed to be $\sigma^{\mathrm{B}}$-independent remained stress-inducible in a $\operatorname{sig} B$ mutant but to a lesser extent than in the wild-type (Krüger et al., 1996; U.
Gerth \& C. Scharf, personal communication). The $c l p C$, $\operatorname{tr} x A$ and $c l p P$ genes are heat- and stress-inducible at two promoters: (i) at a putatively $\sigma^{\mathrm{A}}$-dependent one, typical of the class III mechanism, and (ii) to our surprise, at a $\sigma^{\mathrm{B}}$-dependent one too. The induction by stress at the $\sigma^{\mathrm{A}}$ - 

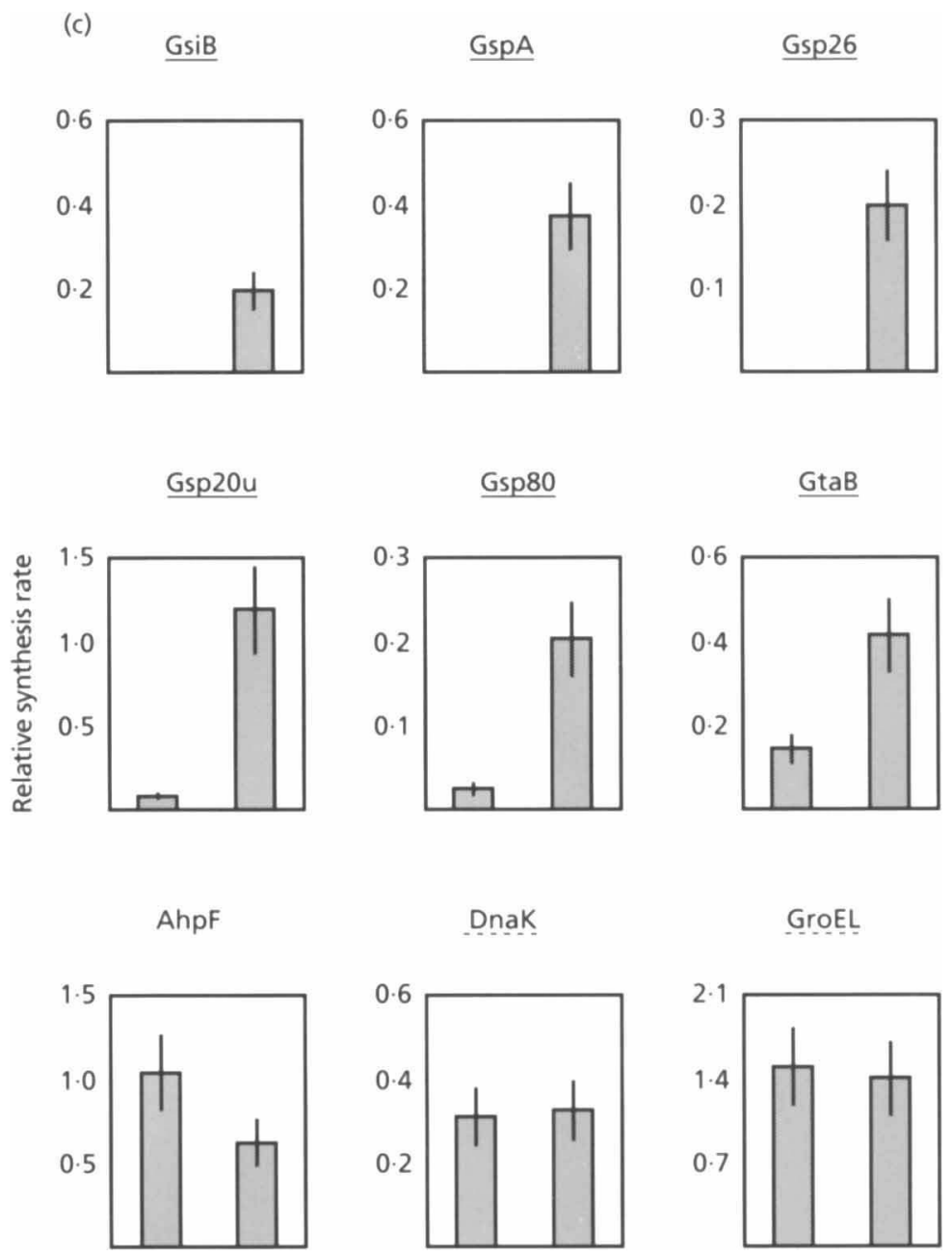

Fig. 5. 2-D pattern of radiolabelled proteins from B. subtilis BSA115 during exponential growth (a) and 30 min after the induction of $\sigma^{\mathrm{B}}$ caused by the addition of $1 \mathrm{mM}$ IPTG (b). Class I heat-shock proteins (dashed lines), class II heat-shock proteins (underlined) and class III heat-shock proteins (not underlined) are indicated. (c) Relative synthesis rates of selected proteins belonging to classes I-III before (first column) and $30 \mathrm{~min}$ after (second column) the addition of $1 \mathrm{mM}$ IPTG.

dependent promoter can partially or completely compensate for the loss of a $\sigma^{\mathrm{B}}$-dependent induction in the sigB mutant. It is tempting to speculate that this double heat shock and stress control by $\sigma^{\mathrm{B}}$ and another so far unknown mechanism may be a typical feature of some of the genes belonging to the class III heat-shock genes of B. subtilis. For example, $\sigma^{\mathrm{B}}$-independent induction only means that $\sigma^{\mathrm{B}}$ is not absolutely required for stress induction, but may be involved in the induction of these genes under some circumstances. For this special group these new results render a strict separation of $\sigma^{\mathrm{B}}$ dependent and $\sigma^{\mathrm{B}}$-independent general stress proteins questionable. Probably, there are many strictly $\sigma^{\mathrm{B}}$ dependent genes (e.g. gspA, gsiB, etc.), a few genes which are controlled by both mechanisms of stress induction (e.g. $c l p C, c l p P$; Krüger et al., 1996; C. Scharf and others, personal communication) and only a few really $\sigma^{\mathrm{B}}$-independent general stress genes (e.g. $a h p C$, ahpF, Antelmann et al., 1996).

The $\sigma^{\mathrm{B}}$ - and CIRCE-independent heat and stress induction mechanism of the class III genes at promoters presumably recognized by $\sigma^{\mathrm{A}}$ involves regulatory elements which have not been defined yet. In contrast to $\sigma^{\mathrm{B}}$-dependent genes, we failed to detect a strong induction by glucose starvation at these promoters. The strong heat induction of $c l p C, c l p P$ and $\operatorname{trx} A$ (" $c l p C$ type') on one hand and the relatively weak induction typical of lon, ftsH, sodM or ahpCF on the other hand suggests that more than one mechanism might be responsible for the induction of this group by stress. We are currently looking for global regulators of class III genes which will help to define new stress regulons. Until these regulators are found and characterized, the al- 
8

$4 \mathrm{pH}$

(a)

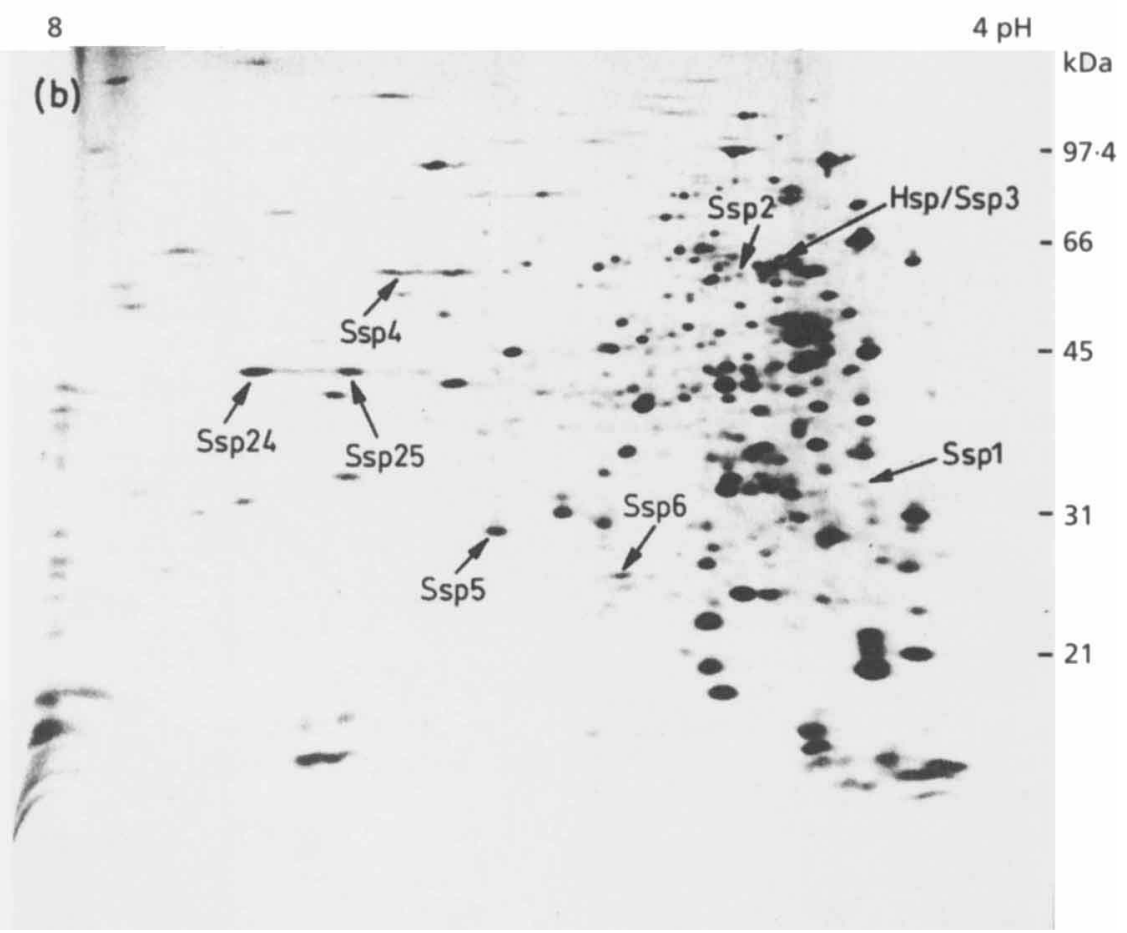

Fig. 6. For legend see p. 1015.

location of genes/proteins to this group is rather arbitrary.

Furthermore, we would like to emphasize that we have already observed overlaps between specific and general stress induction mechanisms. The ahpCF operon, for example, displays a particularly strong induction by $\mathrm{H}_{2} \mathrm{O}_{2}$, besides a rather weak induction by heat and salt stress. In addition to the heat induction mechanism, the ahpCF operon seems to be controlled by a repressor 
8

$4 \mathrm{pH}$

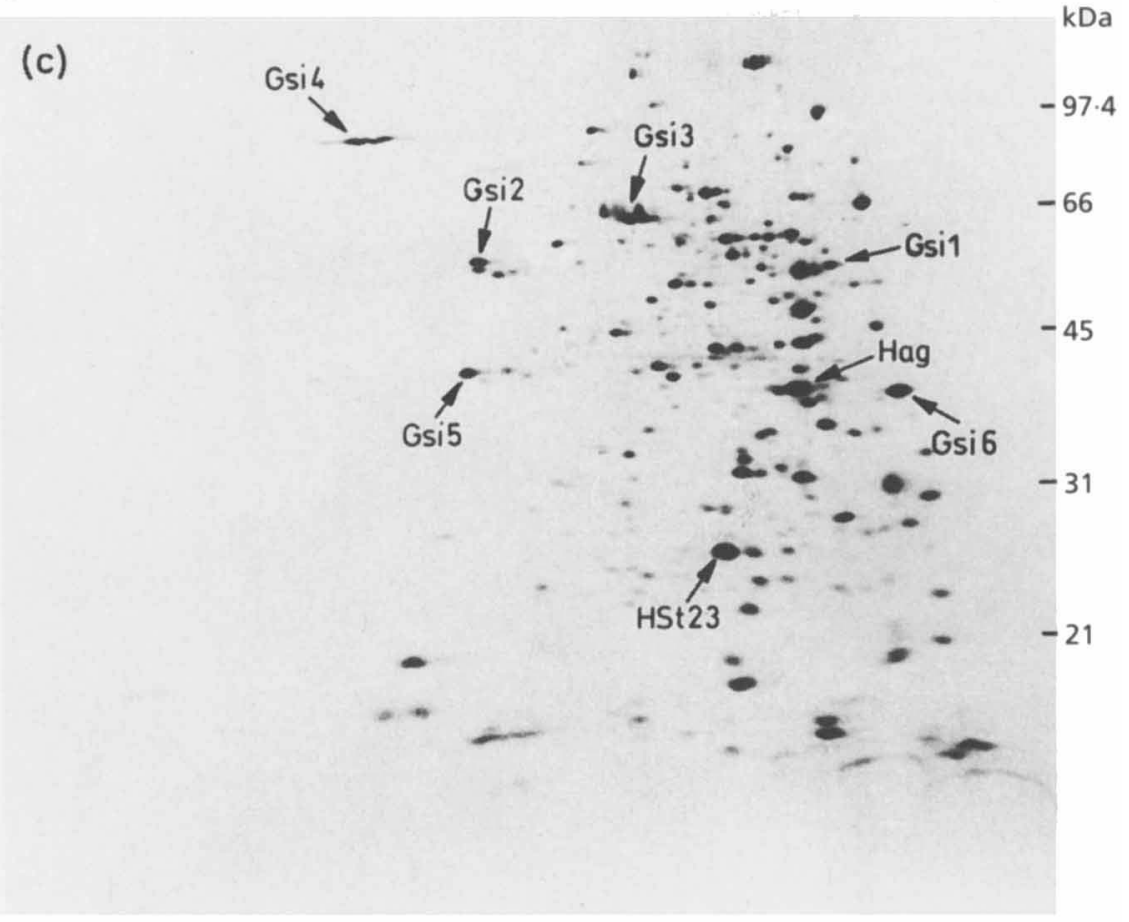

8

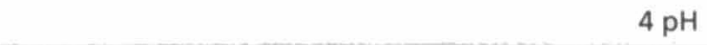

(d)

Fig. 6. For legend see p. 1015.

protein which regulates a peroxide regulon (Chen $e t$ al., 1995 ; Fig. 6). In contrast to other $\sigma^{\mathrm{B}}$-dependent proteins, HSt 23 is strongly induced by amino acid starvation (data not shown), indicating another example for overlapping between a general and specific stress and starvation response. These examples show that a strict distinction between 'specific stress' and 'general stress' proteins might at least in some cases not hold true for the future. Furthermore, it should be stressed that the distinctions are relevant only for the experimental 


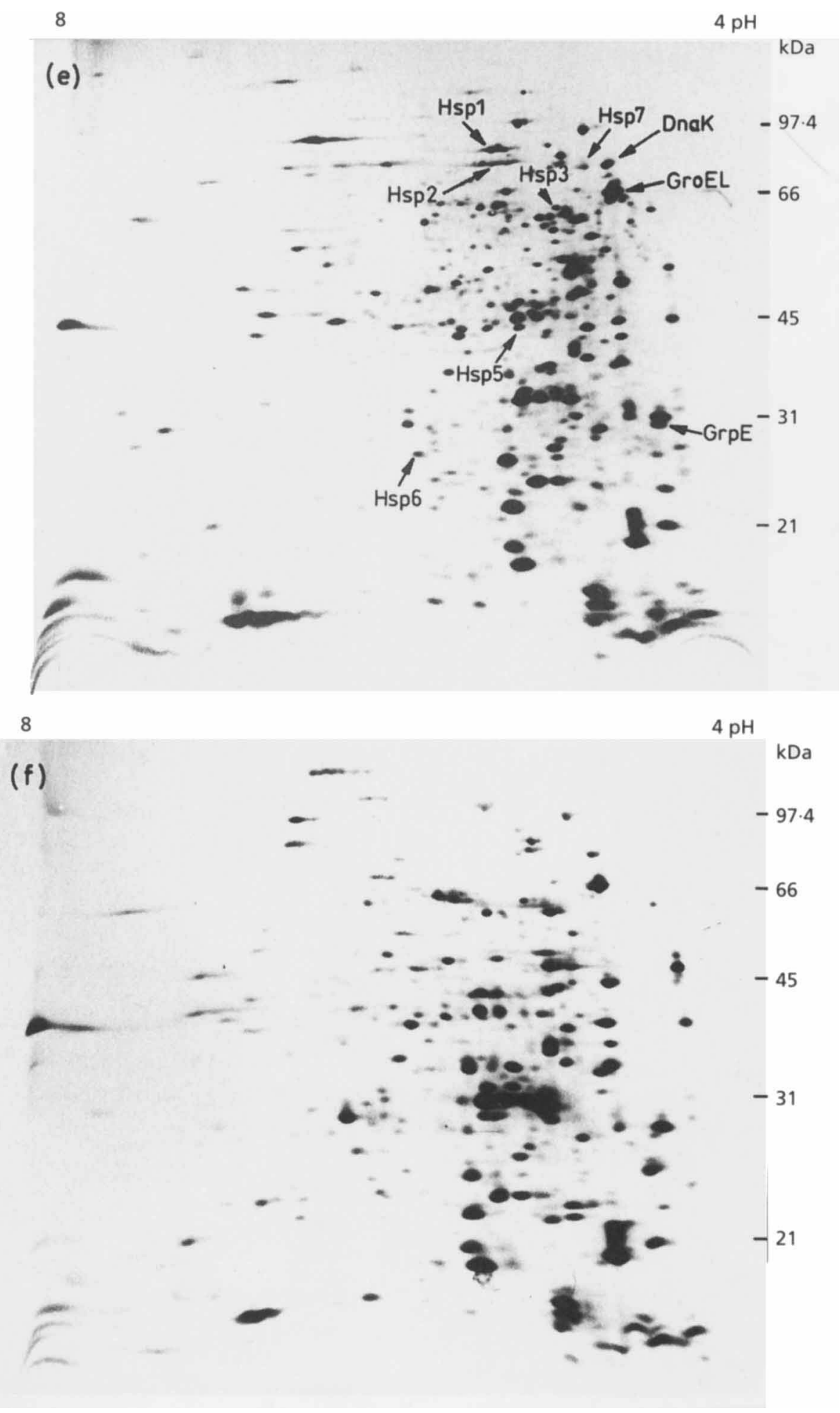

Fig. 6. For legend see facing page.

conditions analysed in this communication and some proteins might need to be reallocated as future work is carried out.

Our results for the induction of specific and general stress proteins in $B$. subtilis demonstrate that the computer-aided analysis of 2-D polyacrylamide gels combined with the establishment of a protein map is a powerful tool for measuring the expression of single genes (proteins) as well as more complex gene 
8

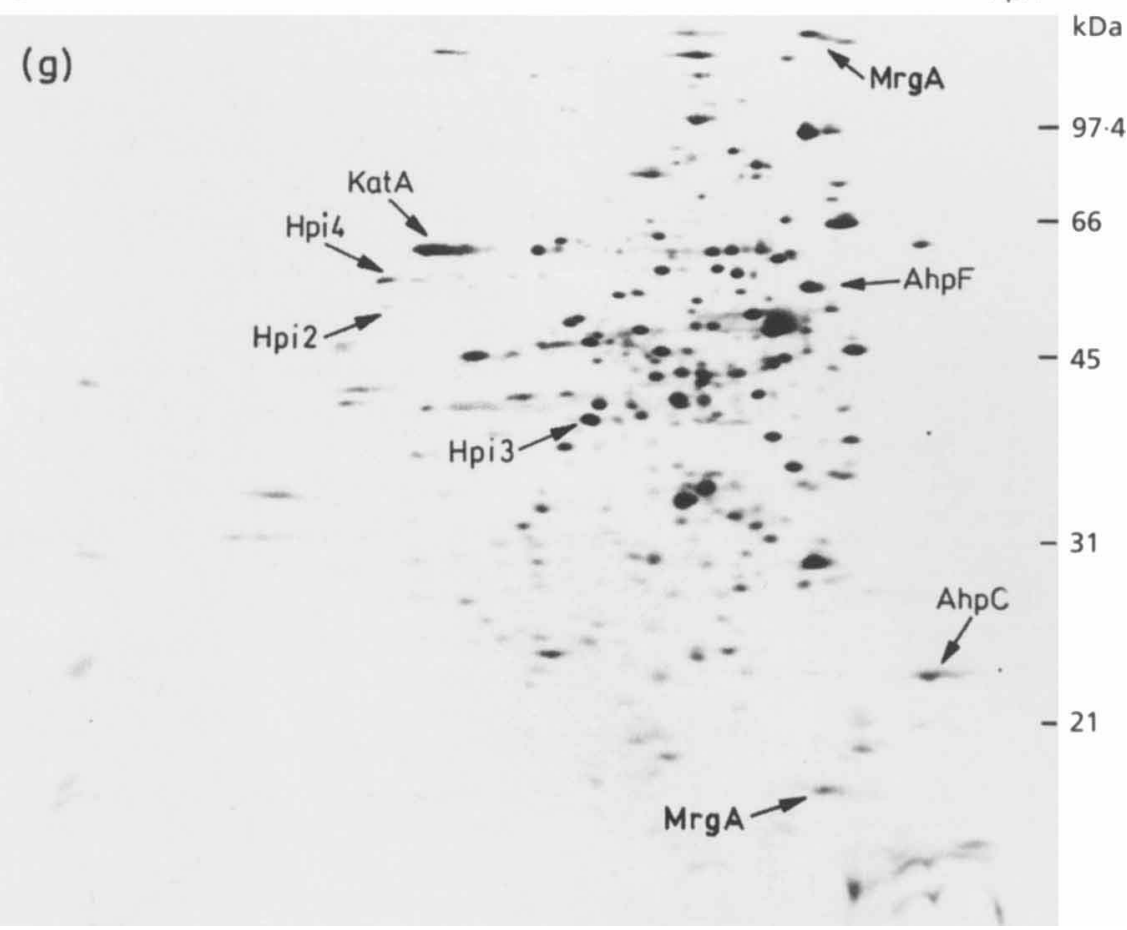

Fig. 6. Stress-specific proteins of B. subtilis. B. subtilis IS58 was grown in synthetic medium, exposed to different stimuli, labelled with L-[35 5$]$ methionine for $3 \mathrm{~min}$ and the crude protein extracts were separated as described in Methods. Bacteria were labelled before (a) and $10 \mathrm{~min}$ after salt (b), heat (e), ethanol ( $f$ ) or oxidative stress ( $g$ ), and $60 \mathrm{~min}$ after entry into stationary phase provoked by glucose (c) or phosphate starvation (d). Ssp, salt-specific stress protein; Hsp, heatspecific stress protein; Hpi, hydrogen-peroxide-induced protein; Gsi, glucose-starvation-induced protein; Psi, phosphatestarvation-induced protein; HSt, heat- and starvation-induced protein.

expression programmes. However, so far we have not been able to visualize the whole set of general stress proteins. For instance, $c l p C$ is the fourth of six genes which are all under the same transcriptional control in a single operon (Krüger et al., 1996), but the remaining five proteins have not been detected on 2-D gels as yet $(S$. Ohlmeier \& E. Krüger, personal communication). Therefore, the $\sigma^{\mathrm{B}}$-regulon might comprise even more than 50 genes and there might be more than $10 \sigma^{\mathrm{B}}$. independent stress genes. After the sequencing of the $B$. subtilis genome, this approach with its ability to investigate the regulation of a large number of single genes simultaneously will contribute especially to the understanding of global regulation of gene expression in Bacillus.

\section{ACKNOWLEDGEMENTS}

This work was supported by grants from the Deutsche Forschungsgemeinschaft, the Fonds der Chemischen Industrie and the BMBF (03109290) to M. H. We thank Karin Binder for excellent technical assistance in 2-D electrophoresis, and Gertrud Schittek and Sabine Schade for continuous support in the preparation of the 2-D gel photographs. Furthermore we would like to thank Hugo Ostermann (Molecular Dynamics, Krefeld) and Erich Lancka (Max Planck Institut für
Molekulare Genetik, Berlin Dahlem) for support with their PhosphorImagers.

\section{REFERENCES}

Abshire, K. Z. \& Neidhardt, F. C. (1993). Analysis of proteins synthesized by Salmonella typhimurium during growth within a host macrophage. J Bacteriol 175, 3734-3743.

Alper, S., Dufour, A., Garsin, D. A., Duncan, L. \& Losick, R. (1996). Role of adenosine nucleotides in the regulation of a stressresponse transcription factor in Bacillus subtilis. J Mol Biol 260, $165-177$.

Anagnostopoulos, C. \& Spizizen, J. (1961). Requirements for transformation in Bacillus subtilis. J Bacteriol 81, 741-746.

Antelmann, H., Bernhardt, J., Schmid, R. \& Hecker M. (1995). A gene at 333 degrees on the Bacillus subtilis chromosome encodes the newly identified $\sigma^{\mathrm{B}}$-dependent general stress protein GspA. $J$ Bacteriol 177, 3540-3545.

Antelmann, H., Engelmann, S., Schmid, R. \& Hecker, M. (1996). General and oxidative stress responses in Bacillus subtilis: cloning, expression and mutation of the alkyl hydroperoxide reductase operon. J Bacteriol 178, 6571-6578.

Benson, A. K. \& Haldenwang, W. G. (1992). Characterization of a regulatory network that controls $\sigma^{\mathrm{B}}$ expression in Bacillus subtilis. J Bacteriol 174, 749-757. 
Benson, A. K. \& Haldenwang, W. G. (1993). Regulation of $\sigma^{\mathrm{B}}$ levels and activity in Bacillus subtilis. J Bacteriol 175, 2347-2356.

Boylan, S. A., Redfield, A. R. \& Price, C. W. (1993). Transcription factor $\sigma^{\mathrm{B}}$ of Bacillus subtilis controls a large stationary phase regulon. J Bacteriol 175, 3957-3963.

Boylan, S. A., Rutherford, A., Thomas, S. M. \& Price, C. W. (1992). Activation of Bacillus subtilis transcription factor $\sigma^{\mathrm{B}}$ by a regulatory pathway responsive to stationary phase signals. $J$ Bacteriol 174, 3695-3706.

Chen, L., Keramati, L. \& Helmann, J. D. (1995). Coordinate regulation of Bacillus subtilis peroxide stress genes by hydrogen peroxide and metal ions. Proc Natl Acad Sci USA 92, 8190-8194.

Dufour, A., Völker, U., Völker, A. \& Haldenwang, W. G. (1996). Relative levels and fractionation properties of Bacillus subtilis $\sigma^{\mathrm{B}}$ and its regulators during balanced growth and stress. $J$ Bacteriol 178, 3701-3709.

Duncan, M. L., Kalman, S. S., Thomas, M. \& Price, C. W. (1987). Gene encoding the 37000-dalton minor sigma factor of Bacillus subtilis RNA polymerase: isolation, nucleotide sequence, chromosomal locus, and cryptic function. J Bacteriol 169, 771-778.

Engelmann, S., Lindner, C. \& Hecker, M. (1995). Cloning, nucleotide sequence, and regulation of katE encoding a $\sigma^{\mathrm{B}}$ dependent catalase in Bacillus subtilis. J Bacteriol 177, 5598-5605.

Eymann, C., Mach, H., Harwood, C. R. \& Hecker, M. (1996). Phosphate-starvation-inducible proteins in Bacillus subtilis - a two-dimensional electrophoresis study. Microbiology 142, 3163-3170.

Glaser, P., Kunst, F., Débarbouillé, M., Vertes, A., Danchin, A. \& Dedonder, R. (1991). A gene encoding a tyrosine tRNA synthetase is located near sacS in Bacillus subtilis. DNA Seq 1, 251-261.

Graumann, P., Schröder, K., Schmid, R. \& Marahiel, M. A. (1996). Cold shock stress-induced proteins in Bacillus subtilis.J Bacteriol 178, 4611-4619.

Hartford, O. M. \& Dowds, B. C. A. (1994). Isolation and characterization of a hydrogen peroxide resistant mutant of Bacillus subtilis. Microbiology 140, 297-304.

Hecker, M. \& Völker, U. (1990). General stress proteins in Bacillus subtilis. FEMS Microbiol Ecol 74, 197-213.

Hecker, M., Schumann, W. \& Völker, U. (1996). Heat-shock and general stress response in Bacillus subtilis. Mol Microbiol 19, $417-428$.

Hilden, I., Krath, B. N. \& Hove-Jensen, B. (1995). Tricistronic operon expression of the genes gcaD (tms), which encodes $N$ acetylglucosamine 1-phosphate uridyltransferase, prs, which encodes phosphoribosyl diphosphate synthetase, and ctc in vegetative cells of Bacillus subtilis. J Bacteriol 177, 7280-7284.

Igo, M., Lampe, M., Ray, C., Schafer, W., Moran, C. P. \& Losick, R. (1987). Genetic studies of a secondary RNA polymerase sigma factor in Bacillus subtilis. J Bacteriol 169, 3464-3469.

Kalman, S., Duncan, M. L., Thomas, S. M. \& Price, C. W. (1990). Similar organization of the $\operatorname{sig} B$ and spollA operons encoding alternative sigma factors of Bacillus subtilis RNA polymerase. $J$ Bacteriol 172, 5575-5585.

Krüger, E., Völker, U. \& Hecker, M. (1994). Stress induction of $c l p C$ in Bacillus subtilis and its involvement in stress tolerance. $J$ Bacteriol 176, 3360-3367.

Krüger, E., Msadek, T. \& Hecker, M. (1996). Alternate promoters direct stress-induced transcription of the Bacillus subtilis clpC operon. Mol Microbiol 20, 713-723.

Loewen, P. C. \& Hengge-Aronis, R. (1994). The role of the sigma factor $\sigma^{\mathrm{s}}$ (KatF) in bacterial global regulation. Annu Rev Microbiol 48, 53-80.

Lottering, E. A. \& Streips, U. N. (1995). Induction of cold shock proteins in Bacillus subtilis. Curr Microbiol 30, 193-199.

Lupi, C. G., Colangelo, T. \& Mason, A. (1995). Two-dimensional gel electrophoresis analysis of the response of Pseudomonas putida KT2442 to 2-chlorophenol. J Environ Microbiol 67, 2863-2872.

Maul, B., Völker, U., Riethdorf, S., Engelmann, S. \& Hecker, M. (1995). $\sigma^{\mathrm{B}}$-dependent regulation of $g s i B$ in response to multiple stimuli in Bacillus subtilis. Mol Gen Genet 248, 114-120.

Miller, B. S., Kennedy, T. E. \& Streips, U. N. (1991). Molecular characterization of specific heat-shock proteins in Bacillus subtilis. Curr Microbiol 22, 231-236.

Moran, C. P., Jr, Johnson, W. C. \& Losick, R. (1982). Close contacts between $\sigma^{37}$-RNA polymerase and a Bacillus subtilis chromosome promoter. J Mol Biol 162, 709-713.

Msadek, T., Kunst, F. \& Rapoport, G. (1994). MecB of Bacillus subtilis, a member of the ClpC ATPase family, is a pleiotropic regulator controlling competence gene expression and growth at high temperatures. Proc Natl Acad Sci USA 91, 5788-5792.

Mueller, J. P., Bukusoglu, G. \& Sonenshein, A. L. (1992). Transcriptional regulation of the Bacillus subtilis glucose starvationinducible genes: control of gsiA by the ComP-ComA signal transduction system. J Bacteriol 174, 4361-4373.

Puglia, A. M., Vohradsky, J. \& Thompson, C. J. (1995). Developmental control of the heat-shock stress regulon in Streptomyces coelicolor. Mol Microbiol 17, 737-746.

Schmid, R., Bernhardt, J., Antelmann, H., Völker, A., Mach, H., Völker, U. \& Hecker, M. (1997). Identification of vegetative proteins for a two-dimensional protein index for Bacillus subtilis. Microbiology 143, 991-998.

Schmidt, A., Schiesswohl, M., Völker, U., Hecker, M. \& Schumann, W. (1992). Cloning, sequencing, mapping, and transcriptional analysis of the groESL operon from Bacillus subtilis. J Bacteriol 174, 3993-3999.

Schulz, A., Tzschaschel, B. \& Schumann, W. (1995). Isolation and analysis of mutants of the dnaK operon of Bacillus subtilis. Mol Microbiol 15, 421-429.

Smith, L., Paress, P., Cabane, K. \& Dubnau, E. (1980). Genetics and physiology of the rel system of Bacillus subtilis. Mol Gen Genet 179, 271-279.

Stulke, J., Hanschke, R. \& Hecker, M. (1993). Temporal activation of $\beta$-glucanase synthesis in Bacillus subtilis is mediated by the GTP pool. J Gen Microbiol 139, 2041-2045.

Tatti, K. M., Kenney, T. J., Hay, R. E. \& Moran, C. P., Jr (1985). Promoter specificity of a sporulation-induced form of RNA polymerase from Bacillus subtilis. Gene 36, 151-157.

VanBogelen, R. A., Sankar, P., Clark, R. L., Bogan, J. A. \& Neidhardt, F. C. (1992). The gene-protein database of Escherichia coli-Edition 5. Electrophoresis 13, 1014-1054.

VanBogelen, R. A., Olson, E. R., Wanner, B. L. \& Neidhardt, F. C. (1996). Global analysis of proteins synthesized during phosphorus restriction in E. coli. J Bacteriol 178, 4344-4366.

Varon, D., Boylan, S. A., Okamoto, K. \& Price, C. W. (1993). Bacillus subtilis gtaB encodes UDP-glucose pyrophosphorylase and is controlled by stationary-phase transcription factor $\sigma^{\mathrm{B}}$. $J$ Bacteriol 175, 3964-3971.

Völker, U., Mach, H., Schmid, R. \& Hecker, M. (1992). Stress proteins and cross-protection by heat shock and salt stress in Bacillus subtilis. J Gen Microbiol 138, 2125-2135. 
Völker, U., Engelmann, S., Maul, B., Riethdorf, S., Völker, A., Schmid, R., Mach, H. \& Hecker, M. (1994). Analysis of the induction of general stress proteins of Bacillus subtilis. Microbiology 140, 741-752.

Völker, U., Dufour, A. \& Haldenwang, W. G. (1995a). The Bacillus subtilis $r s b U$ gene product is necessary for RsbX-dependent regulation of $\sigma^{\mathrm{B}}$. J Bacteriol 177, 114-122.

Völker, U., Volker, A., Maul, B., Hecker, M., Dufour, A. \& Haldenwang, W. G. (1995b). Separate mechanisms activate $\sigma^{B}$ of Bacillus subtilis in response to environmental and metabolic stresses. J Bacteriol 177, 3771-3780.

Wetzstein, M., Völker, U., Dedio, J., Lobau, S., Zuber, U., Schiesswohl, M., Herget, C., Hecker, M. \& Schumann, W. (1992). Cloning, sequencing, and molecular analysis of the dnaK locus from Bacillus subtilis. J Bacteriol 174, 3300-3310.

Wise, A. A. \& Price, C. W. (1995). Four additional genes in the sigB operon of Bacillus subtilis that control activity of the general stress factor $\sigma^{\mathrm{B}}$ in response to environmental signals. J Bacteriol $177,123-133$.
Yang, X., Kang, C. M., Brody, M. S. \& Price, C. W. (1996). Opposing pairs of serine protein kinase and phosphatases transmit signals of environmental stress to activate a bacterial transcription factor. Genes Dev 10, 2265-2275.

Yuan, G. \& Wong, S.-L. (1995a). Regulation of groE expression in Bacillus subtilis: the involvement of the $\sigma^{\mathrm{A}}$-like promoter and the roles of the inverted repeat sequence (CIRCE). J Bacteriol 177, 5427-5433.

Yuan, G. \& Wong, S.-L. (1995b). Isolation and characterization of Bacillus subtilis groE regulatory mutants: evidence for orf 39 in the $d n a K$ operon as a repressor gene in regulating the expression of both groE and dnaK. J Bacteriol 177, 6462-6468.

Zuber, U. \& Schumann, W. (1994). CIRCE, a novel heat shock element involved in regulation of heat shock operon $d n a K$ of Bacillus subtilis. J Bacteriol 176, 1359-1363.

Received 29 May 1996; revised 27 August 1996; accepted 8 October 1996. 